\title{
Invited review: Role of bacterial endotoxins in the etiopathogenesis of periparturient diseases of transition dairy cows
}

\author{
Emily F. Eckel and Burim N. Ametaj ${ }^{1}$ \\ Department of Agriculture, Food and Nutritional Science, University of Alberta Edmonton, AB T6G 2P5, Canada
}

\begin{abstract}
The dairy industry continues to suffer severe economic losses due to the increased disease incidence cows experience during the transition period. It has long been the classical view that the major contributing factor to the development of these periparturient diseases is the considerable increase in nutritional demands for milk production. This classical view, however, fails to account for the substantial correlation between both metabolic and infectious diseases and the detrimental effects that can occur with the provision of high-energy diets to support these nutritional demands. Currently, increasing evidence implicates bacterial endotoxins in the etiopathology of most periparturient diseases. Bacterial endotoxins are components of the outer cell wall of gram-negative and gram-positive bacteria that are highly immunostimulatory and can trigger proinflammatory immune responses. The ability of endotoxins to translocate from the mucosal tissues, including the gastrointestinal tract, mammary gland, and uterus, into the systemic circulation has been observed. Once they have entered the circulation, endotoxins potentially contribute to disease either directly, through eliciting an inflammatory response, or indirectly through other factors such as the overreaction of the natural protective mechanisms of the host. Although the evidence implicating a role of endotoxins in the pathogenesis of transition diseases continues to grow, our current knowledge of the host response to mucosal endotoxin exposure and pathogenic mechanisms remain largely unknown. Developing our understanding of the connection between endotoxemia and dairy cattle disease holds significant potential for the future development of preventative measures that could benefit the productivity of the dairy industry as well as animal welfare.
\end{abstract}

Key words: bacterial endotoxins, dairy cows, periparturient diseases

\footnotetext{
Received December 5, 2015.

Accepted April 2, 2016.

${ }^{1}$ Corresponding author: burim.ametaj@ualberta.ca
}

\section{INTRODUCTION}

It is well known that during the transition period of dairy cows, defined as 3 wk before to 3 wk after calving, a marked increase in the incidence of both metabolic and infectious diseases occurs (Mallard et al., 1998). These diseases continue to cause severe economic losses within the dairy industry regardless of the ongoing attempts to prevent, manage, and treat them. Our current understanding of diseases commonly present around the time of calving, also known as periparturient diseases, is lacking, as half of all dairy cows within a herd are affected by one or multiple diseases, especially during the postpartum period. As such it is necessary to explore new possible mechanisms of pathogenesis to benefit not only dairy industry profitability but also animal welfare and wellbeing.

Efforts have increased from multiple labs worldwide with regard to improving our understanding of the etiopathogenesis of periparturient diseases and developing new prevention technologies. Interestingly, a growing body of evidence supports the possible role of endotoxins in many of these highly detrimental diseases (Andersen, 2003; Ametaj et al., 2010). Endotoxins are membrane components of gram-negative bacteria (GNB) and gram-positive bacteria (GPB) that strongly elicit an immune response when present in the circulation (Draing et al., 2008; Knirel and Valvano, 2011). The physiological changes (i.e., immunosuppression), dietary shift to high grains, and increased exposure to endotoxins [both LPS and lipoteichoic acid (LTA)] at many mucosal tissues during the transition period may be facilitating the development of these periparturient diseases (Mallard et al., 1998; Ametaj et al., 2010).

High-grain diets play a significant role in the development of endotoxemia through the depression of ruminal $\mathrm{pH}$, which eventually leads to the lysis of many ruminal microbiota and subsequently increases the concentration of free endotoxins in the rumen fluid (Mao et al., 2013). Increased endotoxin concentrations are also present at the mammary gland and uterus due to infectious diseases that commonly affect cows postpartum. The ability of endotoxins to translocate into 
the systemic circulation from multiple mucosal sites has been observed, and once an endotoxin has entered the host the natural detoxification processes and the onset of a systemic immune response against endotoxins can contribute to the pathogenesis of multiple diseases simultaneously (Hakogi et al., 1989; Mateus et al., 2003; Ametaj et al., 2010). The aim of the current review is to present the current knowledge of endotoxins, their translocation into the circulation, and their possible role in the etiopathology of multiple periparturient diseases of dairy cows.

\section{FUNCTIONS OF BACTERIAL ENDOTOXINS}

\section{LPS in GNB}

Lipopolysaccharide, also commonly referred to as endotoxin (ET), is a vital component of the outer cell wall of GNB. Lipopolysaccharides contain strong negative charges within their core polysaccharide region that are stabilized by divalent cations present within the membrane. Studies have shown that the structure of LPS influences the architecture and dynamics of naturally forming LPS aggregates, suggesting the differences in LPS among various bacterial species may play a central role in the structure and function of the outer membrane (Knirel and Valvano, 2011). Gramnegative bacteria are also able to release outer membrane vesicles, formed from a bulging out and pinching off of the outer membrane, that are composed mainly of outer membrane components, including LPS, and thus contribute to the release of LPS from live GNB (Mashburn-Warren et al., 2008).

\section{Functions of Lipoteichoic Acid in GPB}

Lipoteichoic acid is a vital component in the cell wall of GPB and shares many pathogenic properties with LPS (Ginsburg, 2002; Draing et al., 2008). Although the term endotoxin is used synonymously with LPS alone, LTA is considered as the endotoxin of GPB. Whereas the functions of LPS in GNB are well documented, those of LTA in GPB are largely unknown at this point. It has been suggested that LTA is likely involved in the proper growth and physiology of bacteria with a role in homeostasis and virulence as evidenced by defects observed in bacteria either lacking LTA or containing mutated forms (Percy and Grundling, 2014). Although less information is available regarding the effects of LTA, as those of LPS have been more extensively studied, compelling evidence exists of its contributing role in bovine disease, which will be further discussed.

\section{SOURCES OF ENDOTOXIN}

\section{Gastrointestinal Tract}

The main source of ET in dairy cattle is the gastrointestinal tract (GIT) due to the microbiome of the rumen, which is rich in both GNB and GPB species, and its sensitivity to dietary changes. Notable changes in the microbial community occur as a result of the shift from high-forage to high-grain diets following parturition, which is common practice within the dairy industry to support high milk production (Tajima et al., 2001; Overton and Waldron, 2004; Mao et al., 2013). Significant evidence has shown that high-grain diets and the resulting depression of ruminal $\mathrm{pH}$ are accompanied by an increase in ruminal LPS concentrations. The reported increases to ruminal LPS vary significantly from 2- to 13.5-fold (Emmanuel et al., 2010; Zebeli et al., 2011a; Zhou et al., 2014).

During high-forage diets, the ruminal $\mathrm{pH}$ remains within a normal range and the microbial community is dominated by the phyla Bacteroidetes and Firmicutes (Jing et al., 2014; Zhang et al., 2014). It has been shown that SARA, induced by feeding rations containing either alfalfa or grain, is associated with a decrease in the proportion of GNB, mainly phylum Bacteroidetes, and an increase in phylum Firmicutes, which are mainly GPB (Khafipour et al., 2009c). Interestingly, it has been shown that intravenous administration of LPS alone can cause the same shift in rumen microbiota from Bacteroidetes to Firmicutes. It was suggested that this shift may be indirectly caused by systemic LPS via VFA accumulation and lowered rumen buffering, leading to depressed ruminal $\mathrm{pH}$. Thus, translocation of LPS into the systemic circulation during SARA may aggravate acidosis and initiate a vicious cycle impairing rumen health (Jing et al., 2014).

Some controversy exists regarding the ability of LPS to translocate from the rumen into the host circulation due to the inconsistency of LPS detection in the peripheral circulation during SARA (Plaizier et al., 2012). Whereas some studies of SARA reported no increase to peripheral LPS (Li et al., 2012; Plaizier et al., 2014), others have observed strong associations between rumen and peripheral LPS concentrations (Khafipour et al., 2009b) as well as increased rumen permeability (Minuti et al., 2014). Early studies addressing ruminal absorption of LPS in steers administered ${ }^{51} \mathrm{Cr}$-labeled Escherichia coli LPS into the rumen (Lassman, 1980; Anderson, 1984) found no evidence of its absorption in the lymphatic system or portal blood and concluded that the ruminal epithelium is impermeable to ET. Interestingly, a prior study by Ravin et al. (1960) in- 
dicated that using ${ }^{51} \mathrm{Cr}$ might affect transport of ET through mucosal membranes, as it attaches firmly to the lipid A moiety and renders it much less emulsifiable and diffusible, precipitating the lipid as an insoluble lipid complex. This might explain why Lassman (1980) and Anderson (1984) found no ${ }^{51}$ Cr-labeled E. coli LPS within the lymphatic circulation or portal blood. Alternatively, data reported by Emmanuel et al. (2007) demonstrated that LPS is able to permeate both the rumen and colon tissues of cattle. Although conflicting results have been reported in regard to the presence of LPS in the blood following increased ruminal LPS concentrations, significant evidence from mice (Ghoshal et al., 2009; Williams et al., 2013) and cattle (Khafipour et al., 2009b) has been found, indicating that LPS cannot only cross the intestinal epithelium but also disrupt the integrity of the intestinal barrier, which will be discussed further in this review.

\section{Mammary Gland}

Another common source of ET is the bovine mammary gland, which is susceptible to bacterial infections. Mastitis is defined as inflammation of the mammary gland and can be caused by both GNB and GPB, although the severity of the infection varies. Grampositive infections result in chronic mastitis due to the ability of the bacteria to colonize within the mammary gland, as LTA elicits a weaker innate immune response compared with LPS, resulting in more long-term infection (Strandberg et al., 2005; Gilbert et al., 2013).

Studies have found that LPS can translocate from the mammary gland into the systemic circulation. Hakogi et al. (1989) and Dosogne et al. (2002) both reported increased plasma LPS during naturally occurring and experimentally induced mastitis, respectively. Hakogi et al. (1989) demonstrated that gangrenous mastitis was associated with a plasma LPS concentration of 85.2 $\pm 68.2 \mathrm{pg} / \mathrm{mL}$, over 18-fold greater than concentrations in the control cows $(4.7 \pm 2.6 \mathrm{pg} / \mathrm{mL})$. Intramammary administration of LPS by Dosogne et al. (2002) caused a significant increase in plasma LPS from less than 10 $\mathrm{pg} / \mathrm{mL}$ maintained in healthy animals to 55 to $134 \mathrm{pg} /$ $\mathrm{mL}$ following inoculation, further suggesting the ability of LPS to translocate from the mammary into the systemic circulation.

\section{Uterus}

Bacterial contamination of the uterus occurs in most cows after parturition, making it another potential source of ET (Sheldon et al., 2002). Studies of uterine inflammation, termed metritis, have indicated that LPS may be able to translocate from the uterus into the circulation based on observed increases to plasma LPS. For example, a positive correlation was found between the severity of metritis and the concentration of LPS in the plasma. Whereas LPS remained mostly undetected in the plasma of healthy and mild metritis cows, it was present in all heavy metritis cows with levels ranging from 2 to $914 \mathrm{pg} / \mathrm{mL}$ (Mateus et al., 2003). Additionally, another study found that LPS was qualitatively detected in the plasma of cows following intrauterine infusion of $5 \mu \mathrm{g} / \mathrm{kg}$ of BW of E. coli whereas control cows were consistently negative. This phenomenon was only observed early postpartum during this study, which suggests that cows are more susceptible to translocation of LPS at this time (Peter et al., 1990).

It should be mentioned that inconsistencies exist in reports of ET concentrations during disease states. Currently, the accurate measurement of LPS within not only the blood but also the GIT and tissues remains difficult and has resulted in inconsistencies that prevent the proper determination of the concentration at which the presence of ET becomes harmful. Multiple factors, such as the individual variability in susceptibility of cattle to systemic LPS (Jacobsen et al., 2005), the rate at which LPS is removed from the circulation, and the measurement technique implemented, likely contribute to the wide variation in reported results. These variations make it difficult to determine what levels of ET should be considered elevated and thus impede the interpretation of how they may contribute to disease.

\section{MECHANISMS OF ET TRANSLOCATION}

Whereas the ability of ET to translocate from the GIT, mammary gland, and uterus is indicated by several studies, the mechanisms are not fully understood. The 2 main possibilities for their movement across the epithelium of various tissues into the circulation are paracellular and transcellular transport (Figure 1; Mani et al., 2012).

\section{Paracellular Transport}

The epithelium of mucosal tissues such as the GIT, uterus, and lactating mammary gland provide a physical barrier from the external environment. These epithelial barriers are typically a single layer of cells joined by tight junction complexes, which are highly regulated. Disruption of tight junction protein complexes increases permeability and allows for the movement of molecules, such as ET, across the epithelium, which would otherwise be excluded to the external environment (Figure 1; Neutra and Kozlowski, 2006; Rainard and Riollet, 2006; Mani et al., 2012). 


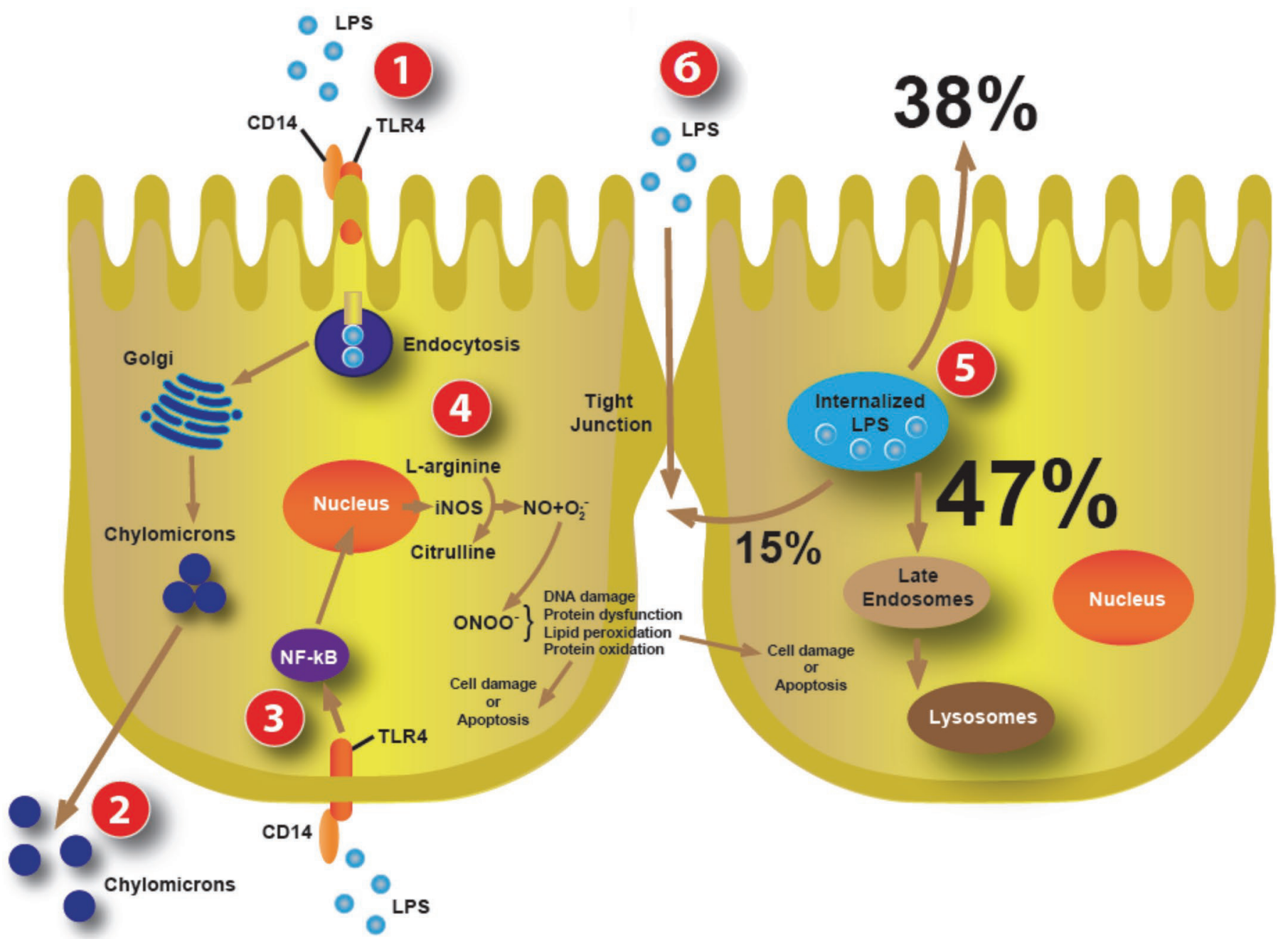

Figure 1. Mechanism of LPS transport in the gastrointestinal tract. (1) Toll-like receptor 4 (TLR4) on the apical membrane binds LPS and triggers receptor mediated endocytosis, endosomes containing LPS are transported to the Golgi apparatus, and chylomicrons produced there have a high affinity for LPS. (2) Chylomicrons, typically responsible for the transportation of long-chain fatty acids (LCFA), which contain LPS enter the lymph and systemic circulation. (3) Stimulation of TLR4 increases the production of nuclear factor $\kappa \mathrm{B}$ (NF- $\kappa \mathrm{B}$ ), a transcription factor that increases the production of proinflammatory cytokines as well as inducible nitric oxide synthase (iNOS). (4) The iNOS catalyzes the production of the free radical nitric oxide (NO), from L-arginine, which can react with superoxide $\left(\mathrm{O}_{2}{ }^{-}\right)$to form peroxynitrite $\left(\mathrm{ONOO}^{-}\right)$. Nitric oxide stimulates cellular injury in an autocrine fashion, whereas $\mathrm{ONOO}^{-}$causes DNA damage, protein dysfunction, lipid peroxidation, and disruption of tight junction proteins. (5) Of the internalized LPS, 38\% is recycled back to the apical side, $47 \%$ is transported to basolateral endosomes that become lysosomes, and $15 \%$ is translocated to the basolateral side. (6) The LPS is additionally able to translocate via paracellular transport when tight junctions are disrupted, which can be caused by exposure to NO. CD14 = cluster of differentiation 14. Color version available online.

Recent research shows that both LPS and LTA can cause disruption of barrier function via increased expression of inducible nitric oxide synthase (iNOS) which in turn increases concentrations of nitric oxide (NO; Figure 1; Korhonen et al., 2002; Singh et al., 2007). Under normal conditions NO is not harmful but rather functions as a potent biological effector and serves many physiological functions, including neurotransmission, vasodilation, and complex roles in the inflammatory response (Boulanger et al., 2001; Woclawek-Potocka et al., 2004; Zaragozá et al., 2010). The concentration of NO typically remains quite low when produced by constructive NO synthase and endothelial NO synthase, but iNOS generates significantly larger quantities (Ding et al., 2004). Various techniques have indicated the role of iNOS, NO, and peroxynitrite $\left(\mathrm{ONOO}^{-}\right.$; formed from the interaction of $\mathrm{NO}$ and $\left.\mathrm{O}_{2}{ }^{-}\right)$ in ET-induced alterations of intestinal epithelial permeability utilizing mouse and rat models (Dickinson et al., 1999; Han et al., 2004).

Increased iNOS expression is observed not only in the intestines but in the endometrium of cows with subclinical endometritis and in the udder during mastitis as well. An in vitro study on the effects of LPS 
and LTA on endothelial tight junctions found that they both cause increased iNOS expression and disruption of tight junctions, leading to increased barrier permeability (Singh et al., 2007). Increased NO has also been observed in the udder during ET-induced mastitis, due to increased production by mammary epithelial cells (MEC) and mononuclear phagocytes, possibly contributing to damage of the mammary tissue during infection (Boulanger et al., 2001).

In addition to disrupting tight junction proteins, $\mathrm{NO}$ and $\mathrm{ONOO}^{-}$are suggested to induce enterocyte apoptosis, potentially via inhibition of cellular respiration and activation of apoptotic cascades (Potoka et al., 2002). Williams et al. (2013) reported that systemic LPS accelerates the rate of apoptosis and intestinal epithelial cell (IEC) shedding exceeding the rate of IEC production and causing gaps in the epithelium of mice. Overall, it can be suggested that translocation of small amounts of LPS may facilitate the passage of larger amounts through increased permeability of epithelial barriers.

\section{Transcellular Transport}

The second possible pathway is transcellular transport and it has been shown that LPS is able to move from the luminal to the basolateral side of polarized intestinal cells, whereas tight junctions remain intact. Studies of LPS internalization from the apical side of IEC have found evidence suggesting this occurs via receptor-mediated endocytosis (Figure 1; Neal et al., 2006).

Several studies suggest that the receptor-mediated endocytosis of LPS occurs by toll-like receptor (TLR) 4, a known pattern recognition receptor (PRR) for LPS (Neal et al., 2006). Under normal conditions the intestinal epithelium is hyporesponsive to bacteria and their components to which it is consistently exposed. This phenomenon can be explained by a low expression of TLR4, myeloid differential protein 2 (MD2) or cluster of differentiation 14 (CD14), all which are necessary for LPS recognition in healthy IEC cells (Abreu et al., 2001; Cario et al., 2002; Abreu, 2010). During states of inflammation and inflammatory disease the expression of TLR and associated signaling proteins can increase and possibly facilitate receptor-mediated endocytosis of LPS (Figure 1; Abreu et al., 2002; Abreu, 2010; Guo et al., 2013). Thus, the presence of inflammation may be a more significant factor in the facilitation of LPS, and possibly LTA, translocation than the concentration of these ET within the rumen or intestines.

The majority of internalized LPS is transported to late endosomes and lysosomal compartments (47\%) or recycled back to the apical side (38\%), with only a small proportion being transcytosed $(15 \%$; Beatty et al., 1999). Endotoxin can also be transported to the Golgi apparatus, which contains newly formed chylomicrons, the lipoproteins responsible for transport of dietary long-chain fatty acids through the mesenteric lymph and blood (Tso and Balint, 1986; Ghoshal et al., 2009). This is significant because chylomicrons have a high affinity for LPS and can deliver it to the lymph and blood, leading to systemic exposure and the associated immune response (Figure 2). High-fat diets, which induce chylomicron formation, have been associated with increased blood LPS in both humans and mice, suggesting that LPS may be transported to the circulation via chylomicrons. The association of LPS with lipoproteins typically has a protective function, which will be discussed further, but this is a multifaceted issue that can result in systemic inflammation (Ghoshal et al., 2009; Grunfeld and Feingold, 2009; Moreira et al., 2012). Although chylomicron synthesis is typically associated with the high-fat diet of preweaned ruminants, they are present in the adult circulation, playing a role in the transport of dietary fatty acids to the tissues for functions, such as milk fat synthesis (Ferreri and Elbein, 1982; Bauchart, 1993), and may contribute to LPS transport at physiological levels.

\section{FATE OF ET IN THE CIRCULATION}

Lipopolysaccharide shed in the GIT, as a result of high grain or high fat, associated with chylomicrons in epithelial cells, is transported into the lymph and triggers release of proinflammatory cytokines by macrophages in mesenteric lymph node (Ghoshal et al., 2009; Figure 2). Part of the ET is transported through the portal vein to the liver where circulating inflammatory cells, Kupffer cells, and hepatocytes scavenge ET to reduce its amount entering the systemic circulation (Trebicka et al., 2011). Kupffer cells are activated and release more proinflammatory cytokines in the systemic circulation (Trebicka et al., 2011). Circulatory proinflammatory cytokines trigger secretion of several acute phase proteins (APP) including serum amyloid A (SAA), haptoglobin (Hp), lipopolysaccharide-binding protein (LBP), and C-reactive protein (Ramadori and Christ, 1999). The latter have multiple functions in removing, neutralizing, or mounting an immune response against ET. A small amount of ET might escape liver macrophages and enter into systemic circulation. Circulatory ET is bound to high-density lipoprotein (HDL) and low-density lipoprotein (LDL), a process facilitated by LBP and soluble (s) CD14 (Munford et al., 1981; Wurfel et al., 1995; Kitchens et al., 1999). Endotoxin bound to lipoproteins will be removed from circulation either by liver hepatocytes or white adipose 
tissue to avoid potential deleterious effects of ET to the host. Endotoxin stored in white adipose tissue is neutralized by local macrophages, triggering secretion of more proinflammatory cytokines that enter into systemic circulation and further contribute to an inflammatory state (Creely et al., 2007).

Research indicates 2 general pathways involved in the removal of LPS once it has entered the bloodstream and, similar to its translocation, the mechanisms are not fully understood. Endotoxin entering plasma seems to bind either to tissue macrophages (i.e., Kupffer cells; Figure 3; Tobias et al., 1989; Wright et al., 1989, 1990) or to lipoproteins, predominantly HDL and chylomicrons (Figure 4; Thaveeratitham et al., 2007; Ghoshal et al., 2009; Feingold and Grunfeld, 2011). The determination of which path LPS will take is determined by at least
4 known factors: concentration of LPS (Sharma et al., 2005; Viktorov and Iurkiv, 2006), LBP, membrane (m) or sCD14, and concentration of cations such as Ca in plasma (Munford et al., 1981).

Endotoxin released by GNB naturally forms aggregates in the plasma due to the amphiphilic structure of the molecule, but it is broken down into monomers through the action of LBP, an APP which increases almost 10-fold during inflammation (Tobias et al., 1989). Lipopolysaccharide-binding protein functions as a lipid transfer molecule, catalyzing 3 distinct reactions: transfer of monomeric LPS to sCD14 or mCD14, transfer of LPS from aggregates to HDL particles, and transfer of LPS from LPS-sCD14 complexes to HDL. These processes result either in the neutralization of LPS, when transferred to lipoproteins, or in cellular

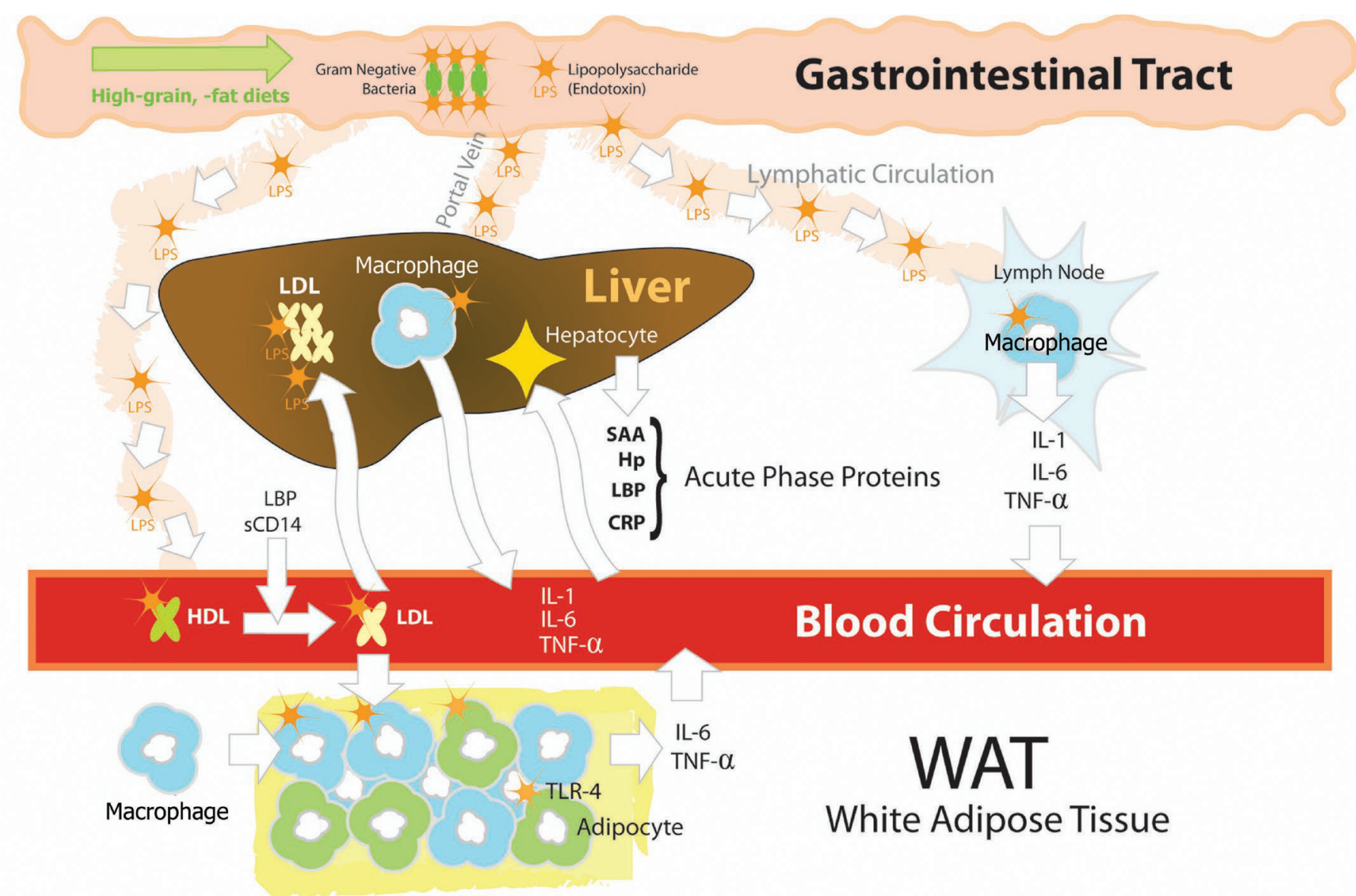

Figure 2. The 3 potential routes of endotoxin (LPS) entry into the host. Diets high in grain or fat trigger release of endotoxin. Endotoxin might enter (1) the lymphatic system, (2) portal vein, or (3) systemic circulation. Endotoxin entering the lymphatic system or portal vein will be removed by local macrophages triggering release of proinflammatory cytokines such as IL-1, IL-6, and tumor necrosis factor (TNF)- $\alpha$. Cytokines are released into systemic circulation and induce production of acute phase proteins in the liver including serum amyloid A (SAA), LPS-binding protein (LBP), haptoglobin (Hp), and C-reactive protein (CRP). In case endotoxin escapes local macrophages in the liver or lymph nodes, it will enter into systemic circulation and bind to high-density lipoprotein (HDL) and low-density lipoprotein (LDL) facilitated by LBP and soluble cluster of differentiation 14 (sCD14). Endotoxin bound to lipoproteins is endocytosed by liver hepatocytes and later released deactivated in the bile, or it might be stored in the white adipose tissue (WAT) and then removed by adipose macrophages, which release more cytokines into the systemic circulation. TLR- $4=$ toll-like receptor 4 . Color version available online. 
activation, when transferred to mCD14 (Hailman et al., 1994; Wurfel et al., 1994, 1995).

\section{Macrophage Pathway}

Membrane-bound CD14 is a protein present on the surface of monocytes, macrophages, and neutrophils (Goyert and Ferrero, 1987) that can bind LPS and trigger the production and release of proinflammatory cytokines, such as tumor necrosis factor (TNF)- $\alpha$, IL1, and IL-6 (Wright et al., 1990; Dobrovolskaia and Vogel, 2002; Mani et al., 2012), as well as NO, superoxide anions, and prostaglandin $\mathrm{E}_{2}\left(\mathbf{P G E}_{\mathbf{2}}\right)$ and $\mathrm{PGF}_{2 \alpha}$ (Figure 3; Nolan, 1981). Whereas the production of cytokines is essential to an immune response against invading pathogens, exaggerated cytokine production can be harmful to the host and lead to septic shock syndrome, typically resulting in multiple organ failure and death (Dobrovolskaia and Vogel, 2002).
A substantial amount of data indicates that the activation of the complement system by bacteria and their products contributes to the direction of LPS to the macrophage pathway (Figure 3; Morrison and Cochrane, 1974; Morrison and Kline, 1977; Kalter et al., 1983). Some activation of the complement system is necessary for the efficient clearance of bacteria or their products, as demonstrated by animal studies. For example, dogs and mice with a genetic C3 deficiency are more susceptible to LPS than healthy littermates because of an impaired clearance of LPS (Quezado et al., 1994; Fischer et al., 1997). Flierl et al. (2008) also demonstrated that C3 and C5 knockout mice had reduced bacterial clearance. Unfortunately, the activation of the complement system in response to ET can also be harmful, as elevated levels of complement protein C5a has been linked to adverse effects such as organ failure and immunoparalysis. Inhibition of the biological effects of C5a in animals suffering from sepsis has

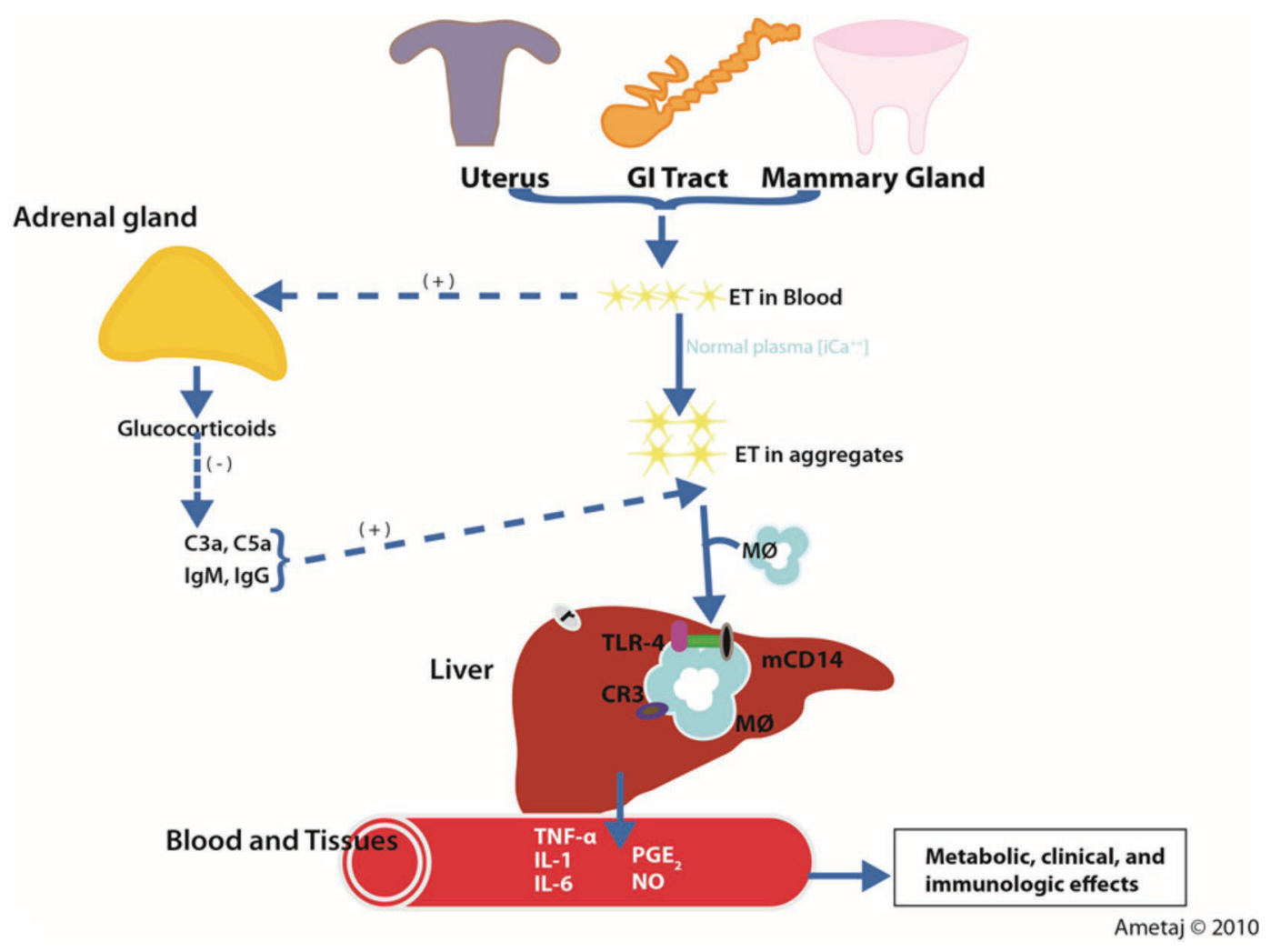

Figure 3. Removal of endotoxin from systemic circulation by macrophage pathway. Endotoxin (ET) is able to translocate into the systemic circulation from mucosal tissues including the uterus, gastrointestinal (GI) tract, and mammary gland. In the presence of ionized calcium $\left(\mathrm{iCa}^{2+}\right)$, at normal physiological concentrations, ET aggregates are formed. Action of circulatory LPS on the adrenal gland increases glucocorticoid production, subsequently inhibiting mechanisms that enhance LPS stimulation of macrophages. Aggregated LPS is separated into monomers to catalyze their transfer to membrane cluster of differentiation 14 (mCD14), which is associated with the toll-like receptor (TLR)-4, resulting in the production of proinflammatory cytokines by macrophages (MØ), such as Kupffer cells in the liver. The production of these proinflammatory cytokines causes downstream metabolic, clinical, and immunologic effects. CR3 $=$ complement receptor CR3; TNF- $\alpha=$ tumor necrosis factor $\alpha ; \mathrm{PGE}_{2}=$ prostaglandin $\mathrm{E}_{2} ; \mathrm{NO}=$ nitric oxide; $\mathrm{C} 3 \mathrm{a}$ and $\mathrm{C} 5 \mathrm{a}=$ complement components. Color version available online. 
been shown to attenuate the lethal complications. This attenuation illustrates that the proinflammatory effects of complement activation, in particular those of C5a, are involved in the pathogenesis of sepsis (Huber-Lang et al., 2001; Flierl et al., 2008). The C5a protein is able to induce or enhance production of cytokines such as TNF- $\alpha$, IL-1, and IL- 6 by monocytes (Cavaillon et al., 1990; Scholz et al., 1990). An interesting observation is that complement interacts with ET only when the latter is present in a state of aggregation with a high molecular weight, which occurs when $\mathrm{Ca}$ ions bind to ET to form aggregates (Galanos and Luderitz, 1976).
Munford and Dietschy (1985) found that homologous antibodies to LPS also favor the macrophage pathway through inhibition of LPS binding to HDL, possibly by blocking LPS disaggregation (Figure 3). Homologous IgG antibodies to LPS are able to opsonize both LPS and preformed LPS-HDL complexes, increasing their uptake by tissues rich in phagocytic cells (i.e., the liver and spleen). These results add to the previous finding by Tate et al. (1966) that specific antibodies increase the apparent density of LPS in the plasma, promote the removal of LPS-HDL from the plasma into tissues, and tend to direct the LPS to the liver and spleen. As

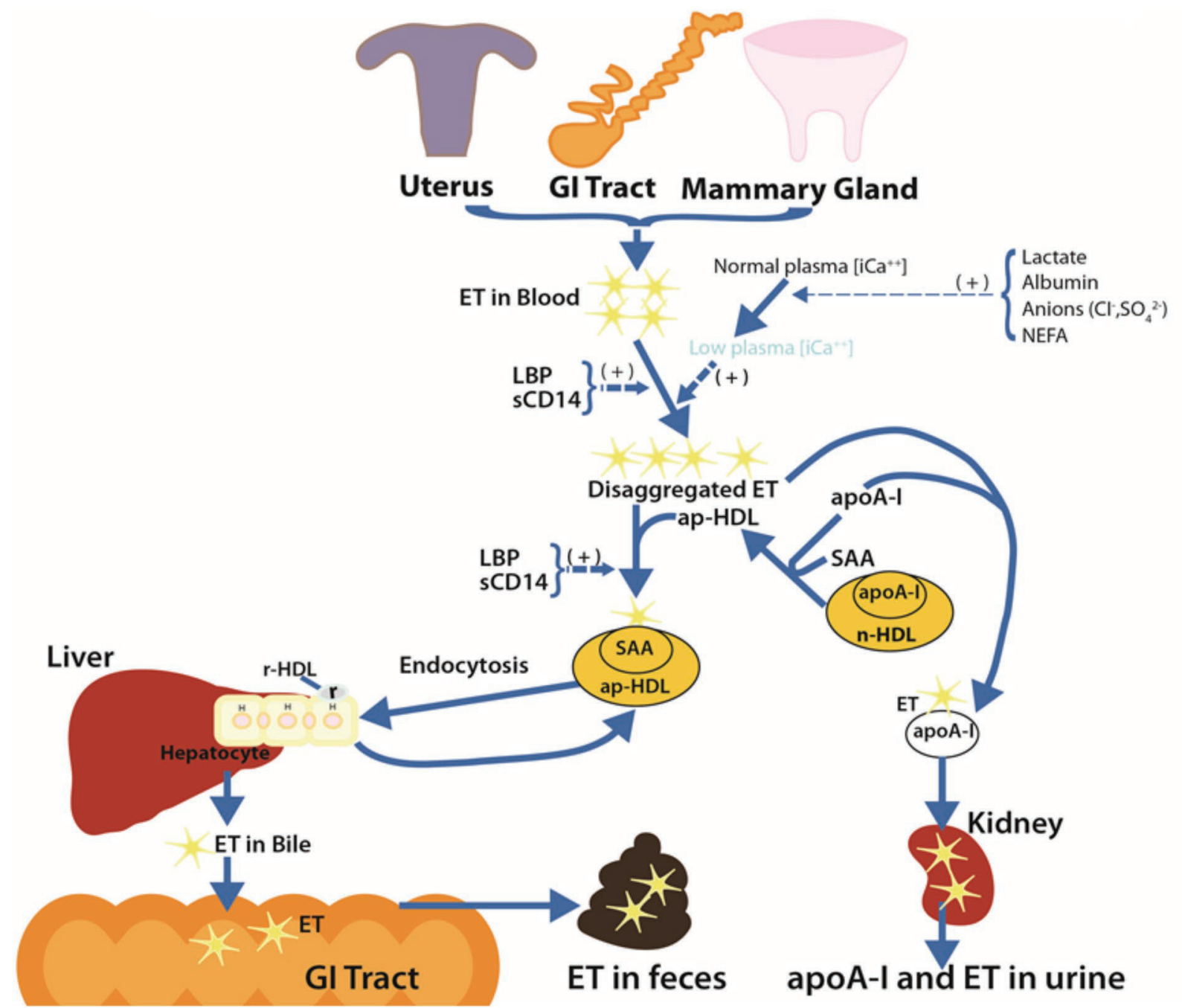

Ametaj $\odot 2010$

Figure 4. Removal of endotoxin from systemic circulation by lipoprotein pathway. Endotoxin (ET) translocates from mucosal tissues, including the uterus, gastrointestinal (GI) tract, and mammary gland, to the systemic circulation. When ionized calcium $\left(\mathrm{iCa}^{2+}\right)$ concentrations in the plasma are decreased the aggregation of ET is inhibited. Plasma lactate, albumin, anions, and fatty acids bind $\mathrm{Ca}^{2+}$ and lower its concentration in the blood. Lipopolysaccharide-binding protein (LBP) binds to ET monomers and catalyzes their transfer to soluble cluster of differentiation 14 (sCD14). Albumin carries $40 \%$ of the bound $\mathrm{Ca}^{2+}$ in the circulation. Soluble CD14 directs LPS to bind acute-phase high-density lipoproteins (ap-HDL) formed by displacement of apolipoprotein (apo) A-I from normal (n) HDL by serum amyloid A (SAA) during the acute phase response. Endotoxin bound to ap-HDL is preferentially shunted to hepatocytes for biliary excretion. Additionally, apoA-I protein can bind and neutralize LPS directly, which is subsequently excreted in the urine. r-HDL = receptor for HDL. Color version available online. 
a conclusion, antibodies to LPS inhibit the binding of LPS to HDL and opsonize both LPS and LPS-HDL complexes for uptake by phagocytic cells; thus, directing the LPS to the macrophage pathway (Munford and Dietschy, 1985).

\section{Lipoprotein Pathway}

The soluble form of CD14 rather than mCD14 plays an important role in directing LPS to HDL or other lipoproteins. Stelter et al. (1998) found that sCD14 prevents binding of LPS to mCD14, inhibiting activation and responses of macrophages. The binding of LPS to macrophages results in the production of inflammatory mediators that amplify and diversify the LPS signal, triggering host defenses that destroy invading bacteria or their toxins. For reasons that are not entirely clear, however, the response to LPS or LTA also can be harmful, resulting in severe sepsis, septic shock, and even death due to a strong systemic response to infection (Van Amersfoort et al., 2003).

High-density lipoproteins are the most abundant of the lipoproteins in bovine plasma ( $>85 \%$; Chapman, 1986; Bauchart, 1993). Increasing evidence points to HDL and other plasma lipoproteins helping to control the host response to LPS. Numerous studies have shown that complexes of LPS with HDL and other lipoproteins have little or no stimulatory activity on immune cells, either in vitro or in vivo (Cavaillon et al., 1990; Baumberger et al., 1991; Wu et al., 2004), and strong evidence indicates that lipoproteins can neutralize LPS in vivo (Levine et al., 1993; Feingold et al., 1995; Contreras-Duarte et al., 2014). Additionally, it is well documented that during the acute phase response significant changes occur to protein synthesis of the liver, such that production of APP is increased whereas that of lipoproteins is decreased (Bertoni and Trevisi, 2013). Several laboratories have also demonstrated that plasma lipoproteins, particularly HDL, bind LPS (Munford et al., 1981; Baumberger et al., 1991; Read et al., 1993b) and preferentially shunt it to hepatocytes and away from hepatic macrophages, thereby increasing LPS excretion via bile and preventing an immune response (Figure 4). Read et al. (1993a) reported that infusion of LPS incubated with chylomicrons increases its biliary excretion by $67 \%$.

Kitchens et al. (1999) showed that lipoproteins can also take up LPS that has first become bound to immune cells. When monocytes are loaded with ${ }^{[3 \mathrm{H}]} \mathrm{LPS}$ and then incubated in plasma, they release over $70 \%$ of the cell-associated ${ }^{[3 \mathrm{H}]}$ LPS into lipoproteins (predominantly HDL), whereas in serum-free medium the ${ }^{[3 \mathrm{H}]}$ LPS remains tightly associated with the cells. Other experiments revealed that $\mathrm{sCD} 14$ enhances LPS release from monocytes (Kitchens et al., 1999), and that LBP can facilitate the transfer of LPS from LPS-sCD14 complexes to HDL (Wurfel et al., 1995). Essentially all of the LPS on the cell surface of monocytes could be released, reducing monocyte responses to LPS and attenuating the immune response of the host.

During an acute phase response the composition of HDL changes significantly. Normal HDL typically contains apolipoprotein A-1; the most notable change during an acute phase response is the displacement of apolipoprotein A-1 with SAA, generating acute phase (ap)-HDL, such that it becomes the major apoprotein representing up to $90 \%$ of HDL apoprotein content. Acute phase-HDL is more rapidly cleared from the circulation and preferentially binds to macrophages, shunting it away from hepatocytes. These changes allow ap-HDL to supply lipid components to damaged tissues and immune cells at the site of inflammation (Khovidhunkit et al., 2000; Carpentier and Scruel, 2002).

\section{Role of Plasma Calcium Concentration in Clearance of LPS}

In dairy cows, infusion of LPS is associated with decreased concentration of total $\mathrm{Ca}$ in the serum in a dose-dependent manner, such that greater amounts of LPS cause more severe reductions to serum Ca (Waldron et al., 2003). Ionized hypocalcemia is a common finding during sepsis in animals as well as humans (Zaloga, 2000; Toribio et al., 2005; Holowaychuk et al., 2009); however, extensive evidence has shown that the administration of Ca during sepsis increases organ failure and mortality. This information suggests that the reduction of serum Ca may be a protective mechanism against endotoxemia (Malcolm et al., 1989; Zaloga et al., 1992; Collage et al., 2013). For example, increasing ionized $\mathrm{Ca}$ in plasma (by $\mathrm{CaCl}_{2}$ administration) from 41 to 49 and $85 \mathrm{mg} / \mathrm{L}$ progressively increases lethality to LPS from 20 to 37 and $80 \%$, respectively. Conversely, administration of the Ca chelator ethylene glycol tetraacetic acid, which lowers the ionized $\mathrm{Ca}$ in plasma to $36 \mathrm{mg} / \mathrm{L}$, decreases LPS-induced mortality to $0 \%$ (Hotchkiss and Karl, 1996).

Numerous studies have demonstrated that Ca plays an important role in the detoxification of LPS. Skarnes and Chedid (1964) suggested that detoxification of LPS by plasma is mediated by a 2 -step reaction in which LPS is first disaggregated and then bound to lipoproteins (Figure 4). This reaction sequence is enhanced by Ca chelators and inhibited by Ca (Skarnes and Chedid, 1964; Skarnes, 1966). Several studies have demonstrated that plasma samples anticoagulated with Ca chelators, such as citrate or EDTA, are able to neutralize greater quantities of LPS than are the corresponding untreated 
sera (Rosen et al., 1958; Skarnes and Chedid, 1964; Skarnes, 1966). Other studies have shown that Ca inhibits binding of LPS to lipoproteins (Munford et al., 1981; Eggesb $\varnothing$ et al., 1996), apparently by preventing the disaggregation of LPS. Munford et al. (1981), for example, reported that $\mathrm{CaCl}_{2}$ prevents disaggregation of LPS, inhibiting binding of LPS to HDL. It is intriguing to suggest that lowered concentrations of $\mathrm{Ca}$ in the plasma of postpartum cows may be a protective response to LPS insults, creating conditions for disaggregation of LPS and its binding to HDL, and therefore neutralization and elimination of LPS from circulation.

Evidence has also been found of an association between lactic acidosis and a decrease in the concentration of ionized $\mathrm{Ca}$, the biologically active form of $\mathrm{Ca}$, in the plasma (Figure 4). For example, Cooper et al. (1992) found a strong association between decreased ionized $\mathrm{Ca}$ and increased lactate concentrations. Additionally, increasing evidence indicates that the concentration of lactate in plasma of subjects suffering from endotoxemia is a good predictor of the development of multiple system organ failure and death (Manikis et al., 1995; Bakker et al., 1996; Mikkelsen et al., 2009). The amount of albumin in blood also affects the concentration of Ca. Albumin binds 1 to 2 calcium ions per molecule and, although the binding affinity is weak and nonspecific, it is the primary carrier for $\mathrm{Ca}$ in plasma, representing up to $40 \%$ of the bound $\mathrm{Ca}$ in the circulation (More and Bulmer, 2013).

Littledike et al. (1970) observed that cows experiencing milk fever had an increase in the concentrations of lactic acid in the blood $(35 \mathrm{mg} / \mathrm{dL})$ compared with that of normal prepartal $(11 \mathrm{mg} / \mathrm{dL})$ and postpartal (14 $\mathrm{mg} / \mathrm{dL}$ ) cows. Infusion of LPS into cattle has also been found to induce alkalosis and hyperlactatemia causing a $50 \%$ increase in the concentrations of lactic acid in plasma (Werling et al., 1996; Ohtsuka et al., 1997; Steiger et al., 1999). Lactate regulates concentrations of Ca in plasma by chelating $\mathrm{Ca}$ ions from free ionized and protein-bound Ca pools (Toffaletti and Abrams, 1989). Therefore, it is possible that increased concentrations of lactic acid in the blood of transition cows suffering from milk fever acts as a protective tool for buffering the ionized Ca pool and facilitating the transfer of LPS to lipoproteins.

Whitsett and Tsang (1977) reported that concentration of ionized $\mathrm{Ca}$ in serum varies inversely and linearly with increasing concentrations of fatty acids and suggested that elevated concentrations of fatty acids might be a factor in the development of hypocalcemia. Several other reports have also indicated that fatty acids bind $\mathrm{Ca}$ and that binding of $\mathrm{Ca}$ to albumin is increased (2-28\%) when long-chain fatty acids, such as palmitic, stearic, and oleic acids, are added to Ca-albumin so- lutions (Ladenson and Shyong, 1977; Aguanno and Ladenson, 1982; Zaloga et al., 1987). It is known that immediately after calving fatty acids are increased in dairy cows (Grummer, 2008). Stevens and Olson (1984) found that binding of fatty acids to ionized Ca occurs also in dairy cows. Thus, fatty acids may also play a role in lowering the concentrations of ionized Ca in cows suffering from milk fever or other ET-related diseases, helping indirectly to neutralize LPS by lipoproteins.

\section{ROLE OF ET IN THE ETIOPATHOGENESIS OF PERIPARTURIENT DISEASES}

It seems that the majority of negative effects associated with ET are caused either by the mechanisms of their removal from the circulation or their ability to trigger a robust and disproportionate immune response (Van Amersfoort et al., 2003). The local response to pathogens is critical for host survival during infection, whereas the systemic activation of the same mechanisms can become deleterious to the host (Seeley et al., 2012). It is through the dysregulation or excessive nature of the host innate immune response to ET, such as LPS and LTA, that may become harmful and contribute to multiple diseases simultaneously.

Central to the innate immune system is the recognition of danger signals, including infection and host damage through PRR. Pattern recognition receptors are able to recognize pathogen-associated molecular patterns in response to pathogen infections or damageassociated molecular patterns, which arise when inflammatory stress occurs, such as host tissue damage. The 2 main families of PRR associated with ET are TLR and nucleotide-binding and oligomerization domainlike receptors (NLR; Khare et al., 2010; Wiersinga et al., 2014).

The TLR responsible for the recognition of LPS and LTA are TLR4 and TLR2, respectively, which are present on immune cells such as macrophages and B cells. It is due to the differences in TLR signaling that LPS and LTA elicit responses that differ in intensity; however, an overlap of signaling pathways exists that cause them to generate responses that are similar in nature (Figure 5; Van Amersfoort et al., 2003; Miyake, 2007; Draing et al., 2008). It is of interest that the structure and subsequent 3-dimensional conformation of LPS, specifically that of a region known as the lipid A moiety, has a direct effect on bioactivity. Highly active and pathogenic varieties of LPS, such as that found in E. coli, possess a conical lipid A structure whereas the lipid A of less active forms assume a cylindrical or intermediate conical shape (Netea et al., 2002). Strong evidence suggests that the intermediate conical lipid A forms stimulate TLR2 rather than TLR4, leading to a 


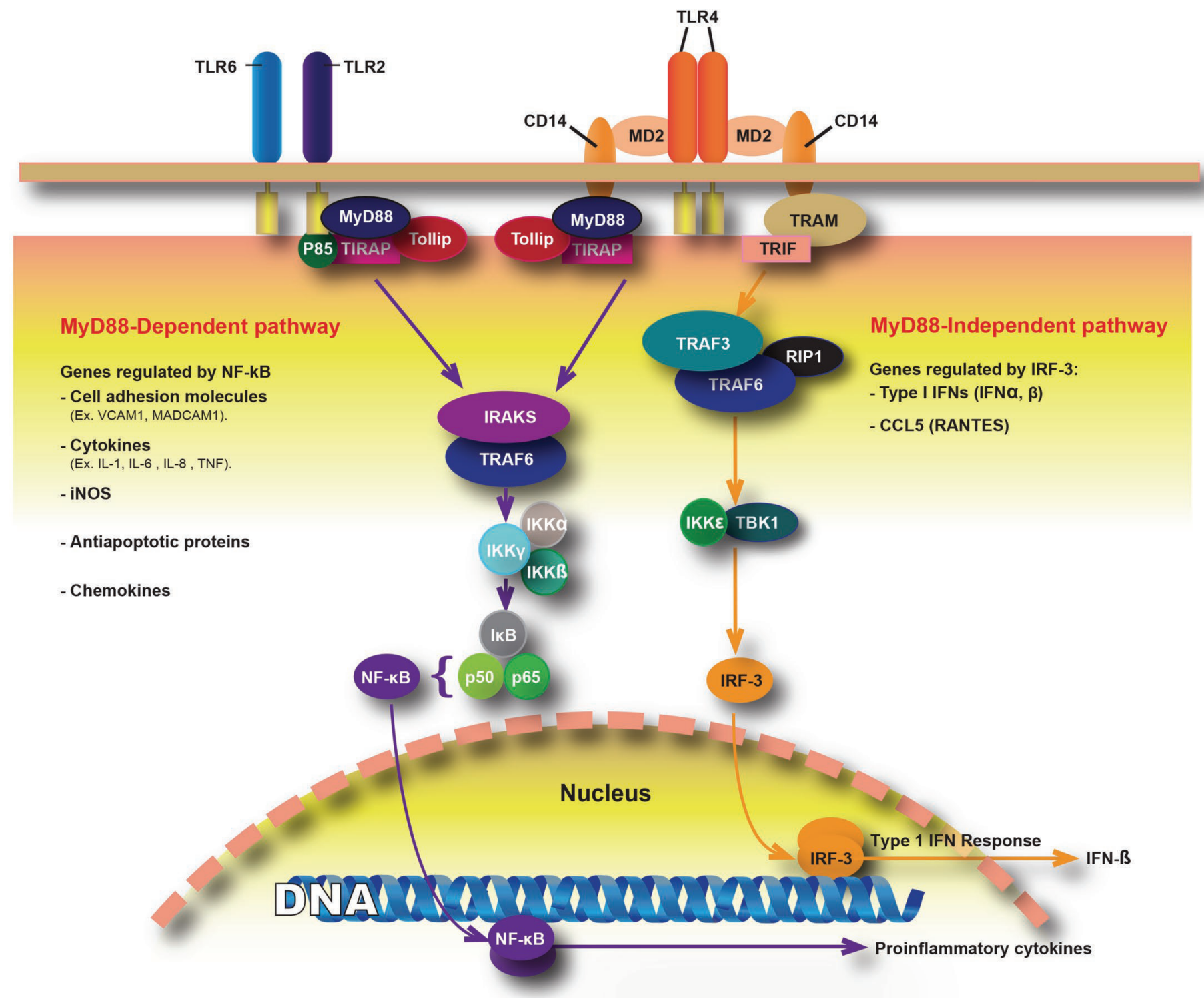

Figure 5. Signaling pathways of toll-like receptors (TLR) stimulated by endotoxins. Typically, LPS from gram-negative bacteria (GNB) stimulates TLR4, whereas lipoteichoic acid (LTA) from gram-positive bacteria stimulates TLR2. Lipopolysaccharide, when bound to LPSbinding protein (LBP), stimulates immune cells with the aid of myeloid differential protein 2 (MD2) and cluster of differentiation 14 (CD14). The intracellular signaling of TLR4 includes 2 pathways: myeloid differentiation factor 88 (MyD88)-dependent and MyD88-independent. The MyD88-dependent pathway, also stimulated by TLR2, uses a complex containing the adaptor proteins MyD88, toll-interleukin 1 receptor (TIR) domain containing adaptor protein (TIRAP), toll interacting protein (tollip), and p85 regulatory subunit, which leads to the translocation of nuclear factor $\kappa \mathrm{B}(\mathrm{NF}-\kappa \mathrm{B})$ into the nucleus, increasing the transcription of genes related to inflammation. The Myd88-independent pathway uses the adaptor proteins TIR-domain-containing adapter-inducing interferon- $\beta$ (TRIF) and TRIF-related adaptor molecule (TRAM) to induce phosphorylation and dimerization of interferon regulatory factor 3 (IRF-3), leading to production of the cytokine IFN- $\beta$. It should be noted that recent evidence indicated that LPS does not exclusively signal via TLR4, but also through TLR2, depending on the conformation of the lipid A moiety. iNOS = inducible nitric oxide synthase; IRAKS = interleukin-1 receptor-associated kinases; RIP1 = receptor interacting protein 1; TBK1 = TANK-binding kinase $1 ; \mathrm{IKK}=\mathrm{IkB}$ kinase; IkB = inhibitor of kappa B; CCL5 (RANTES) = regulated on activation, normal T cell expressed and secreted. Color version available online.

response more commonly associated with that of LTA; cylindrical lipid A, however, has antagonistic properties, inhibiting regular LPS signaling (Erridge et al., 2002; Netea et al., 2002). This is important given the large amounts of ET in the GIT or elsewhere; however, the host may respond only when pathogenic forms of LPS are present.

It is well known that LPS stimulates innate immunity through TLR4 in association with MD2, CD14, and LBP. Lipopolysaccharide-binding protein separates 
LPS aggregates into monomers and presents the LPS/ LBP complex to CD14, which loads LPS onto the receptor complex containing TLR4 and MD2 and causes TLR4 dimerization (Erridge et al., 2002; Miyake, 2007; Mani et al., 2012). The dimerization of TLR4 then leads to activation of intracellular signaling via 2 pathways: MyD88-dependent and MyD88-independent (Figure 5; Miyake, 2007; Mani et al., 2012). The MyD88-dependent pathway leads to the translocation of transcription factor nuclear factor kappa-light-chain-enhancer of activated B cells (NF- $\kappa \mathbf{B}$ ) into the nucleus, which increases the expression of proinflammatory cytokine genes, whereas the MyD88-independent pathway induces phosphorylation and dimerization of interferon regulatory factor 3 and leads to production of IFN- $\beta$ (Netea et al., 2002; Miyake, 2007; Mani et al., 2012). The MyD88-independent pathway for LPS-signaling requires CD14 and LBP whereas the MyD88-dependent pathway does not (Miyake, 2007).

Lipoteichoic acid, on the other hand, stimulates TLR2 and uses CD14, CD36, and LBP (Schröder et al., 2003; Morath et al., 2005). The TLR2 receptor functions as a heterodimer with TLR6 during LTA-dependent activation (Figure 5). The action of TLR2/6 is facilitated by CD36, which is thought to act much as CD14 does with TLR4 and enhances LTA signaling (Mitchell et al., 2007; Nilsen et al., 2008). Similarities in the immune response to LPS and LTA are due to TLR2 also signaling via the MyD88-dependent pathway, causing NF- $\kappa$ B translocation, although unlike LPS it does not signal with the MyD88-independent pathway as well (Mitchell et al., 2007).

Endotoxin-induced TLR stimulation also contributes to the activation of the inflammasome, a signaling protein complex involved in the response to pathogens. Activation of the inflammasome in response to ET occurs via NLR containing a pyrin domain (NLRP), a specific class of NLR. Inflammasome complexes activate proinflammatory caspases that mature proinflammatory cytokines, such as IL-1 $\beta$ and IL-18. The specific inflammasome complex associated with ET is the NLRP3 inflammasome consisting of NLRP3, apoptosis-associated speck-like protein, and caspase-1 (Bauernfeind et al., 2011; Ganz et al., 2011; Pietrocola et al., 2011). Activation of NLRP3 is caused by ligand binding and the consequent oligomerization, leading to association with apoptosis-associated speck-like protein, the protein required to link the NLRP3 receptor with pro-caspase-1 (Khare et al., 2010).

The activation of NLRP3 requires priming and activation steps, both fulfilled by the response to ET. The priming step includes activation of TLR receptors by LPS or LTA and the resulting translocation of NF$\kappa \mathrm{B}$ into the nucleus, which increases the expression of both NLRP3, which is insufficient at basal levels to activate caspase-1, and pro-IL-1 $\beta$ (Bauernfeind et al., 2011). Once priming has occurred, NLRP3 can be activated by various factors such as pathogen-associated molecular patterns (including LPS and LTA), damageassociated molecular patterns, and pathogens (Khare et al., 2010). The activation of NLRP3 leads to the conversion of pro-caspase- 1 into active caspase- 1 , which is an enzyme that cleaves pro-IL-1 $1 \beta$ and pro-IL-18 into the mature proinflammatory cytokines, IL- $1 \beta$ and IL18. The biological effects of IL-1 $\beta$ include fever induction, activation of lymphocytes and epithelial cells, as well as other effects which mediate the inflammatory response, whereas the effects of IL-18 include the activation of natural killer cells and potent induction of INF- $\gamma$ production (Bauernfeind et al., 2011).

It should be taken into account that many of the common transition diseases of dairy cows are multifactorial, meaning that a single factor is not solely responsible for their onset. The downstream effects of the innate immune response that can contribute to the development of these diseases are not solely elicited by LPS and LTA stimulation, but can also be caused by other stimuli (Khare et al., 2010). Thus, although significant evidence exists suggesting that ET play a role in the development of several diseases common to dairy cattle simultaneously, it does not follow that they are the singular cause of their development.

\section{ET AND PERIPARTURIENT DISEASES}

\section{Acute and Subacute Ruminal Acidosis}

An exaggerated intake of highly fermentable carbohydrates causes a shift in the rumen microbiota that favors lactic acid-producing and -utilizing bacteria. This shift leads to accumulation of VFA (SARA) or lactic acid (acute ruminal acidosis) and thus a drop in ruminal pH (Meissner et al., 2010). Ruminal acidosis is characterized by periods of ruminal $\mathrm{pH}$ below 5.5 for extended periods of time where a range of 5.8 to 7.0 is considered normal (Krause and Oetzel, 2006; Meissner et al., 2010). Several studies have found an association between grain-induced SARA and an increase in ruminal LPS concentration (Khafipour et al., 2009a,b; Emmanuel et al., 2010; Zebeli et al., 2011a). It is suggested that the increase in ruminal LPS can be due to either bacterial growth or their lysis. At the onset of SARA GNB proliferation is favored, and as they grow a shedding of LPS occurs; however, as the acidosis persists some of these bacteria can no longer survive, and when they lyse a rapid release of free LPS takes place (Khafipour et al., 2009c; Mao et al., 2013). 
The epithelium of the rumen has a stratified squamous structure (unlike the rest of the GIT, which is a single layer of cells) and a keratinous layer, known as the stratum corneum, is in direct contact with the ruminal milieu. High-grain diets cause a dramatic increase in the proliferation of the epithelium and premature transition of these cells to the keratinous layer, known as parakeratosis (Steele et al., 2011; Plaizier et al., 2012). Steele et al. (2011) observed SARA-associated changes to the rumen epithelium, including sloughing of the stratum corneum and reductions in intracellular organization and thickness of the epithelium. These effects are suggested to cause increased permeability of the ruminal epithelium, and large spaces between the levels of the strata containing large amounts of bacteria have been noted (Steele et al., 2011). It has additionally been observed that LPS alone can cause abnormal keratin production, leading to parakeratosis (Sugita et al., 1986; Singh et al., 1994); this might explain the frequent incidence of parakeratosis during SARA.

Due to not only the structural differences between the ruminal epithelium and that of other tissues but also conflicting results from various studies, it remains unclear whether LPS is, in fact, able to penetrate the rumen in addition to the small intestine and enter the circulation (Plaizier et al., 2012). However, strong evidence exists that during SARA there is disruption of the ruminal epithelium integrity that would allow the translocation of pathogenic molecules, such as LPS, and increase the risk of inflammation (Minuti et al., 2014, 2015). Additionally, some studies have reported evidence of SARA-induced translocation of LPS from the GIT into the circulation which could contribute to systemic inflammation (Gozho et al., 2005; Emmanuel et al., 2007).

\section{Laminitis}

Laminitis is defined as the aseptic inflammation of the dermal layers inside the foot and is one of the top 3 diseases, along with infertility and mastitis, causing increased culling of cows (Nocek, 1997; Government of Canada, 2014). The association of laminitis with ruminal acidosis has been well established, although the etiology remains poorly understood (Ametaj et al., 2010). Acidosis contributes to the development of laminitis through depression of systemic $\mathrm{pH}$ and subsequent activation of vasoactive mechanisms that increase blood pressure in the vasculature of the hoof. This effect is exacerbated by factors such as histamine, biogenic amines, and ET, and ultimately leads to degradation of microvasculature and subsequent swelling and pain. Vessel damage also limits the transport of nutrients to the epidermal cells and eventually causes degradation of the corium and breakdown of the dermal-epidermis junction (Nocek, 1997; Eades, 2010).

High-grain diets are also associated with significant changes to the rumen metabolome that may be involved in development of laminitis (Saleem et al., 2013). The concentration of methylamine was shown to increase with high grain feeding, which may injure blood vessels of the hoof if converted to harmful metabolites including formaldehyde, hydrogen peroxide, and ammonia (Ametaj et al., 2010; Saleem et al., 2012, 2013). An increase in histidine was also observed as a result of grain feeding (Saleem et al., 2013), which may also contribute to laminitis via Allisonella histaminiformans, a ruminal bacterial species that uses histidine and produces histamine, a known aggravator of the vasoactive mechanism associated with laminitis (Garner et al., 2002).

Apart from the role of ruminal acidosis, laminitis has a multifactorial etiology and is believed to develop from interdependent factors including hormone changes, ET, and environmental aspects (Nocek, 1997). Administration of systemic and local LPS doses can cause lesions in the corium and epidermis that are indicative of acute laminitis, implicating its role in this disease (Boosman et al., 1991). The role of LPS in laminitis was further suggested from an in vitro study, which showed its application in cultured equine hoof explants reduced lamellar tissue integrity in a dose-dependent manner (Reisinger et al., 2015), warranting further examination into this area. Researchers also found that cows treated orally with a vaccine against LPS alone or in combination with LTA had lower incidences of laminitis, with the combined LPS and LTA treatment being more effective than LPS alone (Ametaj et al., 2010).

\section{Mastitis}

Mastitis is an inflammatory disease of the udder that is caused by infection with GNB or GPB. The incidence of mastitis remains among the highest of all diseases in cattle and results in devastating economic losses to the dairy industry (Rainard and Riollet, 2006; Jørgensen et al., 2012; Hamadani et al., 2013). Unlike most other epithelial tissues, the mammary epithelium is not normally exposed to bacterial components such that when infection occurs the mammary mounts an immune response, whereas other epithelia have some tolerance for immunogens (Rainard and Riollet, 2006). Bovine MEC have been shown to express TLR-2 and TLR-4, which, as discussed, are PRR for LTA and LPS, respectively, and the expression of these receptors increases during mastitis (Goldammer et al., 2004; Ibeagha-Awemu et al., 2008).

When stimulated by bacteria, bovine MEC are able to produce chemokines, such as IL-8, which at- 
tract the migration of neutrophils. Additionally, upon stimulation with LPS or Staphylococcus aureus bovine MEC can rapidly produce proinflammatory cytokines, namely TNF- $\alpha$, which serves as a central mediator for inflammation. The coordinated production of cytokines and chemokines recruits neutrophils to the udder during infection by increasing the presence of adhesion molecules on endothelial cells that bind neutrophils and allowing them to subsequently move along the concentration gradient of chemoattractants into the mammary (Bannerman et al., 2004; Rainard and Riollet, 2006; Hamadani et al., 2013).

Systemic endotoxemia may play a role in increasing susceptibility to mastitis by delaying the migration of neutrophils into the mammary during the initial infection. Endotoxemia is well associated with the increased release of neutrophils from the bone marrow into the circulation; however, extensive evidence shows that it also inhibits their migration out of the circulation (Wagner and Roth, 1999). The direct effects of LPS as well as the indirect effects through mediators such as NO, discussed previously, result in the inhibition of neutrophil migration (Wagner and Roth, 1999; Dal Secco et al., 2003). These effects may delay the response of neutrophils to infection of the mammary. It should be noted that these inhibitory effects are likely a complex effect of endotoxemia, as the effects of NO alone on bovine neutrophils have been observed to be insufficient in inhibiting migration and functionality (Boulanger et al., 2007).

The majority of economic loss associated with mastitis is due to a reduction in milk production mainly caused by irreversible damage to the mammary tissue. Mammary tissue damage can be caused by bacteria directly; for example, E. coli produces proteolytic enzymes that contribute to the damage of MEC and $S$. aureus produces toxins that directly damage milksecreting tissue and induce necrosis (Kerro Dego et al., 2002; Zhao and Lacasse, 2008).

\section{Retained Placenta}

The etiology of retained placenta $(\mathbf{R P})$, defined as the failure to expel the placental membranes within $24 \mathrm{~h}$ after calving, is largely associated with immune dysfunction. An immune response against the fetal membranes is critical in the normal degradation of the cotyledon-caruncle attachment that separates the placental membrane from maternal tissue (LeBlanc, 2008). A lower concentration of IL- 8 in the plasma of cows that develop RP suggests that part of the dysfunction is associated with reduced recruitment of neutrophils to the cotyledon, as this is the function of IL- 8 in addition to increasing collagenase secretion, which helps separate the connection between maternal and placental tissues. Additionally, cows with RP also exhibit neutrophils with reduced oxidative burst activity (Kimura et al., 2002; LeBlanc, 2008).

The possible role of LPS in the etiology of RP has been recently established as parenteral administration of increasing doses of LPS over 3 consecutive weeks to dairy cows around parturition and was associated with a significantly higher incidence of RP. It was suggested that the exposure of neutrophils to LPS before calving may cause development of LPS tolerance, a phenomenon where tolerized cells have reduced expression of TLR4 and thus a weaker response to LPS (Zebeli et al., 2011b). The development of adaptive immunity following repeated subclinical exposure to LPS may contribute to the diminished response of the host to subsequent exposure. The development of tolerance or resistance to LPS indicates the host can more efficiently recognize and remove LPS from the circulation through the mobilization of both innate and adaptive immunity.

The diminished response of neutrophils may prevent the immune response necessary to stimulate the separation of maternal and fetal tissues required for normal membrane expulsion. This hypothesis was further supported by a study of utero-placental gene expression that found reduced expression of not only leukocyte adhesion molecules but also proinflammatory cytokines associated with the immune response to LPS (i.e., IL-1, IL-6, IL-8, and TNF- $\alpha$ ) in animals with RP (Boro et al., 2014). Bacterial toxins have also been observed to stimulate synthesis of $\mathrm{PGE}_{2}$ by the caruncle and allantochorion, which further contributes to immunosuppression (Slama et al., 1994). It should be noted as well that RP also contributes to the development of uterine disease as the lochia serves as a medium for bacterial growth within the uterus (Dohmen et al., 2000).

\section{Metritis, Endometritis, and Infertility}

Postpartum uterine contamination and the immune suppression that occurs around parturition are major factors favoring persistent bacterial infection and the development of uterine diseases (Mallard et al., 1998; Azawi, 2008). Metritis and endometritis are characterized as inflammation of the uterine tissues and have been shown to contribute significantly to infertility in cattle. Metritis occurs within the first $21 \mathrm{~d}$ postpartum, most commonly within the first $10 \mathrm{~d}$, and involves all uterine tissues (i.e., the endometrium, submucosa, muscularis, and serosa). Endometritis, on the other hand, is inflammation of only the endometrial layer, with clinical endometritis typically characterized as the presence 
of purulent vaginal discharge after $21 \mathrm{~d}$ postpartum and has an incidence of about 10 to $20 \%$ in dairy cows (Sheldon and Dobson, 2004; Sheldon et al., 2009a).

Uterine disease is a key concern to dairy producers, as it is the most common cause of infertility. Both metritis and endometritis are associated with a significant reduction in reproductive performance, as affected animals have increased days open, lower conception rates, delayed first service, and increased culls for reproductive failure (Gilbert et al., 2005; Williams et al., 2008). Moreover, bacterial infection and inflammation prolong the luteal phase, impair the function of the hypothalamus and pituitary, and disrupt ovarian steroidogenesis (Williams et al., 2008; Sheldon et al., 2009b). Furthermore, as corpus luteum (CL) diameter was smaller during the first postpartum cycle in cows with many versus fewer uterine pathogens, it was concluded that metritis has deleterious effects on ovarian function and contributes to infertility (Williams et al. 2007).

Increasing evidence has shown that the mechanism by which LPS or ET affects reproductive functions is both local and systemic. During endometritis, Herath et al. (2007) showed that LPS is increased more than 2,900 fold in the follicular fluid of affected cows (176 vs. $0.06 \mathrm{ng} / \mathrm{mL}$ in healthy controls), suggesting that $\mathrm{ET}$ is able to translocate from uterus to CL. The same authors also reported that LPS is able to inhibit production of both estradiol $\left(\mathbf{E}_{2}\right)$ and progesterone $(\mathbf{P} 4)$ by bovine granulosa cells; however, the effects of LPS are not only short-lived. Bromfield and Sheldon (2013) proposed that exposure to LPS during uterine infection has long-term consequences on the follicular reserve, leading to infertility even after resolution of infection.

The mechanism by which LPS affects CL and reproduction functions is based on the fact that epithelial and stromal cells of the bovine endometrium as well as granulosa cells in the CL (Herath et al., 2007; Lüttgenau et al., 2016) express TLR2, TLR4, MD-2, and CD14 mRNA, allowing them to mount an immune response against GPB and GNB infections associated with detrimental downstream effects (Williams et al., 2008; Cronin et al., 2012; Turner et al., 2014). Moreover, LPS in vitro has been shown to trigger granulosa cells to overexpress a variety of cytokines including IL6, IL-1 $\beta$, IL-10, TNF- $\alpha$, IL-8, and CCL5 mRNA (Price et al., 2013). More details on this topic are available in a review by Turner et al. (2012).

Several groups of investigators have significantly contributed on the mechanistic aspects of how LPS affects reproductive functions of dairy cows. For example, it was reported that LPS prolongs the luteal phase through switching of prostaglandin production from $\mathrm{PGF}_{2 \alpha}$ to $\mathrm{PGE}_{2}$, preventing luteolysis (Williams et al., 2008; Herath et al., 2009; Sheldon et al., 2009b).
An in vitro study on the effects of TNF- $\alpha$ and $\mathrm{NO}$ on bovine endometrial cells found that $\mathrm{TNF}-\alpha$ increases iNOS activity in stromal cells and NO preferentially stimulates $\mathrm{PGE}_{2}$ production, which may be the mechanism of this luteoprotective effect (Herath et al., 2009). The ability of bacterial infection to disrupt ovulation in cattle has additionally been observed in vitro, with TNF- $\alpha$ decreasing theca cell androstenedione production, the precursor to $\mathrm{E}_{2}$, and both LPS and TNF- $\alpha$ reducing granulosa cell $\mathrm{E}_{2}$ production. Interruption of $\mathrm{E}_{2}$ production prevents the LH surge, which subsequently delays ovulation and causes the development of cystic follicles (Williams et al., 2008; Sheldon et al., 2009b). The inhibition of $\mathrm{P} 4$ and androstenedione production from theca cells has also been observed following stimulation with peptidoglycan, a component of GPB that stimulates TLR2 (Magata et al., 2014), which may also implicate LTA as it also signals via TLR2. Furthermore, Herzog et al. (2012) reported a temporary suppression of CL function and structure after intravenous administration of LPS in diestrus, nonlactating cows. Luteal size and concentration of $\mathrm{P} 4$ decreased within $24 \mathrm{~h}$ after LPS treatment. Similarly, when LPS was given $42 \mathrm{~h}$ after $\mathrm{PGF}_{2 \alpha}$ (used to induce regression of CL and ovulation), formation of CL was delayed compared with control cows (Suzuki et al., 2001). Bromfield and Sheldon (2013) explored the mechanism by which LPS affects long-term functioning of CL. They found that LPS was able to increase the number of activated primordial follicles in bovine ovarian follicles ex vivo. Those authors speculated that premature activation of primordial follicles can deplete ovarian follicle reserve and, therefore, have long-lasting consequences on the reproductive performance of transition dairy cows.

Mounting evidence also indicates that not only infection of the uterus but also of the udder affects ovarian and CL functions in dairy cows. Recently, Lavon et al. (2011) demonstrated that inducing mastitis with E. coli LPS or $S$. aureus exosecretions was associated with decreased concentrations of follicular $\mathrm{E}_{2}$, androstenedione, and P4 in the E. coli LPS group at 40, 13, and 35\%, respectively, whereas in the $S$. aureus exosecretions group only $\mathrm{E}_{2}$ decreased by $56 \%$. In the same line of research, Asaf et al. (2014) showed that induction of mastitis by LPS from E. coli or $S$. aureus exosecretions affected distribution of matured oocytes by decreasing the number of oocytes that cleaved to 2- and 4-stage embryos and the rate of blastocyst formation. In addition, a study conducted by Melendez et al. (2003) reported a strong association between lameness and ovarian cyst and fertility in transition dairy cows. They reported that cows affected by lameness within $30 \mathrm{~d}$ after calving were 2.63 times more likely to develop an ovarian cyst before first breeding. Lameness also was negatively 
related with conception rate at first service, with lame cows less likely to conceive at first service than nonlame cows. Although those authors do not provide data for a cause-effect relationship between lameness and ovarian and reproductive performance of those cows, this might be an interesting area to be explored in the future.

Lipopolysaccharide has been shown to influence the release of hormones in the hypothalamus and pituitary. For example, Battaglia et al. (2000) showed that LPS interrupted the preovulatory increase in concentrations of $\mathrm{E}_{2}$ and delayed or blocked the subsequent $\mathrm{LH}$ and FSH surges in the ewe. The same authors indicated that LPS interfered with the preovulatory sequence of endocrine events via suppression of LH pulsatility, although ovarian responsiveness to gonadotropin stimulation also was disrupted. Moreover, Coleman et al. (1993) demonstrated in experiments conducted with portal vein cannulation that LPS lowers secretion of $\mathrm{GnRH}$ from the hypothalamus and the release of $\mathrm{LH}$ and FSH (Coleman et al., 1993). Overall, it seems likely that ET are able to disrupt hypothalamus-pituitaryovary axis in cows with infections and have long-term consequences on reproductive performance of transition dairy cows.

\section{Fatty Liver}

Fatty liver is characterized by the storage of triglycerides (TG) or triacylglycerols within hepatocytes. Conventionally, this disease is viewed as the result of the negative energy balance and subsequent mobilization of fatty acids from adipose tissue, which are then taken up by the liver hepatocytes in excess causing conversion to TG for storage or partial oxidation to ketones for energy (Grummer, 2008; Ametaj et al., 2010). Several indicators from recent research, however, suggest that the development of fatty liver cannot be fully explained by this conventional theory.

The potential role of ET in the etiology of fatty liver is strongly suggested by multiple studies (Figure 6). For example, a positive correlation exists between fatty liver and development of other common periparturient diseases that are not related to negative energy balance, such as metritis and mastitis, which are bacterial infections (Ametaj et al., 2010). A possible mechanism of fatty liver development in association with LPS is through the lipoprotein pathway, which was discussed earlier. The association of LPS with HDL and chylomicrons, normally a protective mechanism, may cause deleterious effects to the host when large amounts of LPS are present in the circulation.

The preferential shunting of lipoprotein-associated LPS to hepatocytes in large quantities may cause accumulation of TG once LPS has been removed via bile (Munford, 2005; Ghoshal et al., 2009; Ametaj et al., 2010). This possible mechanism of TG accumulation is further supported by the observation that the association of LPS and HDL increases its uptake by hepatocytes (Vishnyakova et al., 2003; Tran-Dinh et al., 2013). A study conducted by Bradford et al. (2009) found that injection of TNF- $\alpha$ alone in late-lactation dairy cows promoted the storage of roughly double the amount TG in the liver compared with controls. As such, the immune response to LPS, which stimulates TNF- $\alpha$ production, would contribute to fatty liver as well. Their study also found reduced transcription of necessary genes for gluconeogenesis further supporting the hypothesis, as reduced glucose production also occurs during fatty liver (Bradford et al., 2009). A similar study did not observe increased TG storage in response to TNF- $\alpha$ in early-lactation cows, although they observed reduced feed intake and milk production and an increase in the incidence of ketosis (Yuan et al., 2013). Interestingly, recent studies of nonalcoholic fatty liver disease in mice and rats have shown that gut-derived ET plays a role in the development of this disease and further that treatment with probiotics can help protect against fatty liver (Endo et al., 2013; Ritze et al., 2014).

Cows experiencing fatty liver are shown to be in a state of inflammation and have higher circulating concentrations of APP and cytokines, such as TNF- $\alpha$ (Bobe et al., 2004; Ametaj et al., 2005, 2010). The distinct connection between fatty liver and inflammation can be observed by increases in SAA, Hp, fatty acids, and TG in the plasma, as well as decreases in cholesterol (Bertoni et al., 2003; Bertoni and Trevisi, 2013). Serum amyloid A and Hp are APP that, respectively, bind ET, aiding their removal by the liver via lipoproteins, and bind hemoglobin, preventing the bacterial uptake of iron. Likely triggers of increased SAA and Hp are IL-1 and IL-6, which are produced in the liver by Kupffer cells following ET stimulation. Decreased plasma cholesterol is also likely associated with ET via increased bile production for detoxification and removal (Ametaj et al., 2005, 2010).

\section{Displaced Abomasum}

Displaced abomasum (DA) is also a multifactorial disease, characterized by varying degrees of displacement and distension of the abomasum, that affect an average of 5 to $7 \%$ of dairy cows (Wittek et al., 2004; LeBlanc et al., 2005). The top 3 risk factors of DA include decreased ruminal fill, high-concentrate diets, and increased incidence of other diseases such as fatty liver, RP, metritis, and mastitis. It is proposed that the key elements in the pathogenesis of DA include a lack of ruminal fill, which increases the opportunity for 
the migration of the abomasum, and abomasal atony (reduced motility); however, its etiology continues to be poorly understood (LeBlanc et al., 2005; Shaver, 1997).

Several factors point to ET as contributing to the development of DA, the first being reduced feed intake caused by ET challenge (Steiger et al., 1999). Additionally, many diseases that are associated with DA (i.e., ruminal acidosis, fatty liver, metritis, RP, and mastitis) have suggested roles of ET in their development or possibly contribute to its translocation into the circulation (Cameron et al., 1998; Zadnik, 2003; Zebeli et al., 2011b). Interestingly, Zebeli et al. (2011b) reported an increased incidence of DA in cows treated with parenteral doses of LPS for 3 consecutive weeks. Additionally, in vitro and in vivo experiments have described the ability of ET to reduce motility of the abomasum, one of the key factors that contributes to this disease (van Miert et al., 1977; Vlaminck et al., 1985; Kaze et

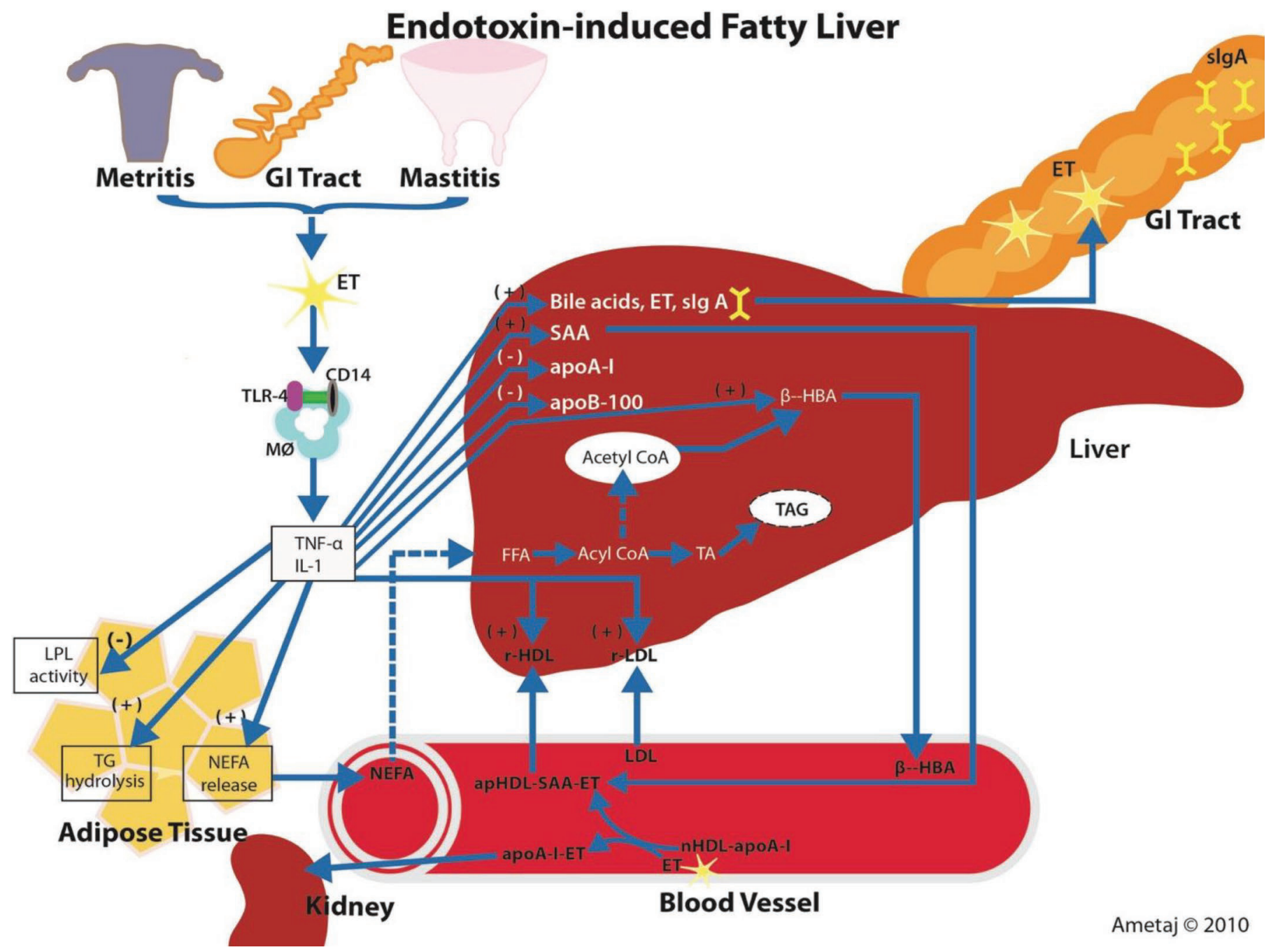

Figure 6. Potential role of endotoxin in triggering of fatty liver. Endotoxin (ET) translocates from mucosal tissues, including the uterus, gastrointestinal (GI) tract, and mammary gland, to the systemic circulation. Stimulation of macrophages by ET occurs through toll-like receptor 4 (TLR4) and results in increased production of proinflammatory cytokines such as tumor necrosis factor (TNF)- $\alpha$ and IL-1. Downstream effects of LPS-induced cytokines include the inhibition of lipoprotein lipase (LPL) and increased hydrolysis of triglycerides resulting in release of fatty acids into the circulation. When fatty acid concentrations entering the liver are too high, the result is partial oxidation of free fatty acids (FFA) to $\beta$-hydroxybutyric acid ( $\beta$-HBA) and increased conversion of FFA to triacylglyceride (TAG) for storage. Increased TAG production increases their storage within hepatocytes that is characteristic of fatty liver. Endotoxin bound to low-density lipoproteins (LDL) and acute phase highdensity lipoproteins (apHDL) is also removed from systemic circulation by respective receptors (r-HDL and r-LDL), increasing storage of TAG in the liver even further. Proinflammatory cytokines (TNF- $\alpha$ and IL-1) also induce production of serum amyloid A (SAA) but suppress production of apolipoprotein (apo) B-100 and apoA-1. Moreover, cytokines trigger production of bile acids that play a role in excreting the neutralized endotoxin and the release of anti-endotoxin secretory $\operatorname{IgA}(\mathrm{sIgA})$; at the same time they inhibit apoA-1 and apo-B. As a consequence the very LDL assembly and secretion from liver is reduced and is associated with accumulation of TAG in the liver. CD14 = cluster of differentiation 14; $\mathrm{nHDL}=$ normal high density lipoprotein; $\mathrm{TG}=$ triglycerides; $\mathrm{M} 0=$ macrophage; $\mathrm{TA}=$ triacylglycerols. Color version available online. 
al., 2004). There is a high association of hypocalcemia and DA, which may be a result of reduced serum Ca common during endotoxemia, discussed previously, and may indirectly contribute to the reduced motility of the abomasum (Shaver, 1997; Zadnik, 2003; LeBlanc et al., 2005).

Cows with DA also show signs of an immune response against ET in their serum. Evidence of leukocytosis with neutrophilia (increased neutrophils in the blood) in cows with DA and increased Hp in the plasma are evident during DA, which further implicates the role of ET in DA (Zadnik, 2003; Stengärde et al., 2010; Zebeli et al., 2011b). It should be noted, however, that a study of endotoxemia in relation to DA found contradictory evidence to this hypothesis, as animals with DA had a lower prevalence of endotoxemia, warranting further research in this area (Wittek et al., 2004).

\section{Milk Fever}

Milk fever, or parturient paresis, can be described as clinical hypocalcemia, and an average of 5 to $10 \%$ of cattle are affected by this disease postpartum, with $15 \%$ of those unresponsive to treatment resulting in downer cow syndrome (Gray et al., 2007). As discussed previously, serum Ca plays an important role in the fate of systemic ET, and dairy cows infused with LPS show dose-dependent reductions in serum Ca concentrations (Waldron et al., 2003). The current prevention method for hypocalcemia is via management of the DCAD in the feed as well as the provision of dietary Mg. However, milk fever remains an issue in the dairy industry regardless of these management techniques and has been identified as a risk factor for other periparturient diseases, such as mastitis, RP, ketosis, and DA (DeGaris and Lean, 2008; Ametaj et al., 2010).

Endotoxemia has been linked to hypocalcemia and hypomagnesemia, as well as other electrolyte disturbances in various species. The direct association of endotoxemia and reduced plasma concentrations of $\mathrm{Ca}$ and phosphorous in cows (Waldron et al., 2003), along with a decrease in magnesium and an increase in plasma parathyroid hormone in horses, has been observed (Toribio et al., 2005).

Increased concentration of the APP, SAA and calcitonin-gene related peptide, suggest the role of inflammation in milk fever (Ametaj et al., 2010; Zebeli et al., 2013). A paper by Gray et al. (2007) provides further evidence that immunity is involved in the etiology of milk fever, including the ability of IL- $1 \beta$ to trigger reduction in plasma $\mathrm{Ca}$, the heritability of susceptibility as seen by breed predisposition, and a case study which found a recumbent cow to have demyelination of the spinal cord which has been induced by TNF- $\alpha$ in mice and rats (Gray et al., 2007). More research is warranted to further clarify the precise role of ET in the pathobiology of milk fever.

\section{CONCLUSIONS}

Overall, the information presented in this review strongly suggests that ET play a significant role in the development of multiple periparturient diseases currently affecting transition dairy cows. The broad nature of the effects ET have on the host, including barrier disruption, stimulation of protective mechanisms, and the production of a robust immune response, contributes to the development of multiple diseases that are known to be associated, yet have seemingly unrelated causes. Given the mounting evidence of their role in many of the diseases that cause the most economic loss to the dairy industry it is important to continue expanding our knowledge of ET and to develop possible preventative measures against their actions on the host. Although more information is available for the role of LPS, several studies indicate a contribution of LTA in these diseases as well, which demonstrates a need to also increase research efforts in this area.

\section{ACKNOWLEDGMENTS}

We thank Alberta Livestock and Meat Agency Ltd. (Edmonton, Alberta, Canada), Alberta Milk (Edmonton, Alberta, Canada), and Natural Sciences and Engineering Research Council of Canada (Ottawa, Ontario, Canada) for their ongoing financial support of our research.

\section{REFERENCES}

Abreu, M. T. 2010. Toll-like receptor signalling in the intestinal epithelium: How bacterial recognition shapes intestinal function. Nat. Rev. Immunol. 10:131-144.

Abreu, M. T., E. T. Arnold, L. S. Thomas, R. Gonsky, Y. Zhou, B $\mathrm{Hu}$, and M. Arditi. 2002. TLR4 and MD-2 expression is regulated by immune-mediated signals in human intestinal epithelial cells. J. Biol. Chem. 277:20431-20437.

Abreu, M. T., P. Vora, E. Faure, L. S. Thomas, E. T. Arnold, and M. Arditi. 2001. Decreased expression of Toll-like receptor-4 and MD-2 correlates with intestinal epithelial cell protection against dysregulated proinflammatory gene expression in response to bacterial lipopolysaccharide. J. Immunol. 167:1609-1616.

Aguanno, J. J., and J. H. Ladenson. 1982. Influence of fatty acids on the binding of calcium to human albumin. Correlation of binding and conformation studies and evidence for distinct differences between unsaturated fatty acids and saturated fatty acids. J. Biol. Chem. 257:8745-8748.

Ametaj, B. N., B. J. Bradford, G. Bobe, R. A. Nafikov, Y. Lu, J. W Young, and D. C. Beitz. 2005. Strong relationships between mediators of the acute phase response and fatty liver in dairy cows. Can. J. Anim. Sci. 85:165-175.

Ametaj, B. N., Q. Zebeli, and S. Iqbal. 2010. Nutrition, microbiota, and endotoxin-related diseases in dairy cows. Rev. Bras. Zootec. 39:433-444. 
Andersen, P. H. 2003. Bovine endotoxicosis - Some aspects of relevance to production diseases. A review. Acta Vet. Scand. Suppl. 98:141-155.

Anderson, S. D. 1984. Endotoxic and anaphylactic-type shock in steers from intravenous injection of Escherichia coli endotoxin and ruminal absorption of endotoxin. MS Thesis. Kansas State Univ., Manhattan.

Asaf, S., G. Leitner, O. Furman, Y. Lavon, D. Kalo, D. Wolfenson, and Z. Roth. 2014. Effects of Escherichia coli- and Staphylococcus aureus-induced mastitis in lactating cows on oocyte developmental competence. Reproduction 147:33-43.

Azawi, O. I. 2008. Postpartum uterine infection in cattle. Anim. Reprod. Sci. 105:187-208.

Bakker, J., P. Gris, M. Coffernils, R. J. Kahn, and J. Vincent. 1996. Serial blood lactate levels can predict the development of multiple organ failure following septic shock. Am. J. Surg. 171:221-226.

Bannerman, D. D., M. J. Paape, J. W. Lee, X. Zhao, J. C. Hope, and P. Rainard. 2004. Escherichia coli and Staphylococcus aureus elicit differential innate immune responses following intramammary infection. Clin. Diagn. Lab. Immunol. 11:463-472.

Battaglia, D. F., H. B. Krasa, V. Padmanabhan, C. Viguie, and F. J. Karsch. 2000. Endocrine alterations that underlie endotoxininduced disruption of the follicular phase in ewes. Biol. Reprod. 62:45-53.

Bauchart, D. 1993. Lipid absorption and transport in ruminants. J. Dairy Sci. 76:3864-3881.

Bauernfeind, F., A. Ablasser, E. Bartok, S. Kim, J. Schmid-Burgk, T. Cavlar, and V. Hornung. 2011. Inflammasomes: Current understanding and open questions. Cell. Mol. Life Sci. 68:765-783.

Baumberger, C., R. J. Ulevitch, and J. M. Dayer. 1991. Modulation of endotoxic activity of lipopolysaccharide by high-density lipoprotein. Pathobiology 59:378-383.

Beatty, W. L., S. Meresse, P. Gounon, J. Davoust, J. Mounier, P. J. Sansonetti, and J. P. Gorvel. 1999. Trafficking of Shigella lipopolysaccharide in polarized intestinal epithelial cells. J. Cell Biol. 145:689-698.

Bertoni, G., and E. Trevisi. 2013. Use of the liver activity index and other metabolic variables in the assessment of metabolic health in dairy herds. Vet. Clin. North Am. Food Anim. Pract. 29:413-431.

Bertoni, G., E. Trevisi, A. Ferrari, and M. Bionaz. 2003. Energy and protein metabolism and liver activity changes in dairy cows treated with E. coli endotoxin 3 day after calving. Pages 299-302 in Progress in Research on Energy and Protein Metabolism. W. B. Souffrant and C. C. Metges, ed. Wageningen Academic Publishers, Wageningen, the Netherlands.

Bobe, G., J. W. Young, and D. C. Beitz. 2004. Invited review: Pathology, etiology, prevention, and treatment of fatty liver in dairy cows. J. Dairy Sci. 87:3105-3124.

Boosman, R., C. W. Mutsaers, and A. Klarenbeek. 1991. The role of endotoxin in the pathogenesis of acute bovine laminitis. Vet. Q. 13:155-162.

Boro, P., A. Kumaresan, A. K. Singh, D. Gupta, S. Kumar, A. Manimaran, A. K. Mohanty, T. K. Mohanty, R. Pathak, N. M. Attupuram, R. K. Baithalu, and S. Prasad. 2014. Expression of short chain fatty acid receptors and pro-inflammatory cytokines in utero-placental tissues is altered in cows developing retention of fetal membranes. Placenta 35:455-460.

Boulanger, V., L. Bouchard, X. Zhao, and P. Lacasse. 2001. Induction of nitric oxide production by bovine mammary epithelial cells and blood leukocytes. J. Dairy Sci. 84:1430-1437.

Boulanger, V., X. Zhao, K. Lauzon, and P. Lacasse. 2007. Effects of nitric oxide on bovine polymorphonuclear functions. Can. J. Vet. Res. 71:52-58.

Bradford, B. J., L. K. Mamedova, J. E. Minton, J. S. Drouillard, and B. J. Johnson. 2009. Daily injection of tumor necrosis factor- $\alpha$ increases hepatic triglycerides and alters transcript abundance of metabolic genes in lactating dairy cattle. J. Nutr. 139:1451-1456.

Bromfield, J. J., and I. M. Sheldon. 2013. Lipopolysaccharide reduces the primordial follicle pool in the bovine ovarian cortex ex vivo and in the murine ovary in vivo. Biol. Reprod. 88:98.
Cameron, R. E., P. B. Dyk, T. H. Herdt, J. B. Kaneene, R. Miller, H. F. Bucholtz, J. S. Liesman, M. J. Vandehaar, and R. S. Emery. 1998. Dry cow diet, management, and energy balance as risk factors for displaced abomasum in high producing dairy herds. J. Dairy Sci. 81:132-139.

Cario, E., D. Brown, M. McKee, K. Lynch-Devaney, G. Gerken, and D. K. Podolsky. 2002. Commensal-associated molecular patterns induce selective toll-like receptor-trafficking from apical membrane to cytoplasmic compartments in polarized intestinal epithelium. Am. J. Pathol. 160:165-173.

Carpentier, Y. A., and O. Scruel. 2002. Changes in the concentration and composition of plasma lipoproteins during the acute phase response. Curr. Opin. Clin. Nutr. Metab. Care 5:153-158.

Cavaillon, J. M., C. Fitting, and N. Haeffner-Cavaillon. 1990. Recombinant C5a enhances interleukin 1 and tumor necrosis factor release by lipopolysaccharide-stimulated monocytes and macrophages. Eur. J. Immunol. 20:253-257.

Chapman, M. J. 1986. Comparative analysis of mammalian plasma lipoproteins. Methods Enzymol. 128:70-143.

Coleman, E. S., T. H. Elsasser, R. J. Kemppainen, D. A. Coleman, and J. L. Sartin. 1993. Effect of endotoxin on pituitary hormone secretion in sheep. Neuroendocrinology 58:111-122.

Collage, R. D., G. M. Howell, X. Zhang, J. L. Stripay, J. S. Lee, D. C. Angus, and M. R. Rosengart. 2013. Calcium supplementation during sepsis exacerbates organ failure and mortality via calcium/ calmodulin-dependent protein kinase kinase signaling. Crit. Care Med. 41:e352-e360.

Contreras-Duarte, S., P. Varas, F. Awad, D. Busso, and A. Rigotti. 2014. Protective role of high density lipoproteins in sepsis: Basic issues and clinical implications. Rev. Chilena Infectol. 31:34-43.

Cooper, D. J., K. R. Walley, P. M. Dodek, F. Rosenberg, and J. A. Russell. 1992. Plasma ionized calcium and blood lactate concentrations are inversely associated in human lactic acidosis. Intensive Care Med. 18:286-289.

Creely, S. J., P. G. McTernan, C. M. Kusminski, M. Fisher, N. F. Da Silva, M. Khanolkar, M. Evans, A. L. Harte, and S. Kumar. 2007. Lipopolysaccharide activates an innate immune system response in human adipose tissue in obesity and type 2 diabetes. Am. J. Physiol. Endocrinol. Metab. 292:E740-E747.

Cronin, J. G., M. L. Turner, L. Goetze, C. E. Bryant, and I. M. Sheldon. 2012. Toll-like receptor 4 and MYD88-dependent signaling mechanisms of the innate immune system are essential for the response to lipopolysaccharide by epithelial and stromal cells of the bovine endometrium. Biol. Reprod. 86:51-73.

Dal Secco, D., J. A. Paron, S. H. de Oliveira, S. H. Ferreira, J. S. Silva, and Q. Cunha Fde. 2003. Neutrophil migration in inflammation: nitric oxide inhibits rolling, adhesion and induces apoptosis. Nitric Oxide 9:153-164.

DeGaris, P. J., and I. J. Lean. 2008. Milk fever in dairy cows: A review of pathophysiology and control principles. Vet. J. 176:58-69.

Dickinson, E., R. Tuncer, E. Nadler, P. Boyle, S. Alber, S. Watkins, and H. Ford. 1999. NOX, a novel nitric oxide scavenger, reduces bacterial translocation in rats after endotoxin challenge. Am. J. Physiol. 277:G1281-G1287.

Ding, L. A., J. S. Li, Y. S. Li, N. T. Zhu, F. N. Liu, and L. Tan. 2004. Intestinal barrier damage caused by trauma and lipopolysaccharide. World J. Gastroenterol. 10:2373-2378.

Dobrovolskaia, M. A., and S. N. Vogel. 2002. Toll receptors, CD14, and macrophage activation and deactivation by LPS. Microbes Infect. 4:903-914.

Dohmen, M. J., K. Joop, A. Sturk, P. E. Bols, and J. A. Lohuis. 2000. Relationship between intra-uterine bacterial contamination, endotoxin levels and the development of endometritis in postpartum cows with dystocia or retained placenta. Theriogenology 54:10191032 .

Dosogne, H., E. Meyer, A. Sturk, J. van Loon, A. M. Massart-Leen, and C. Burvenich. 2002. Effect of enrofloxacin treatment on plasma endotoxin during bovine Escherichia coli mastitis. Inflamm. Res. 51:201-205.

Draing, C., S. Sigel, S. Deininger, S. Traub, R. Munke, C. Mayer, L. Hareng, T. Hartung, S. von Aulock, and C. Hermann. 2008. 
Cytokine induction by gram-positive bacteria. Immunobiology 213:285-296.

Eades, S. C. 2010. Overview of current laminitis research. Vet. Clin. North Am. Equine Pract. 26:51-63.

Eggesb $\varnothing$, J. B., T. Lyberg, T. Aspelin, I. Hjermann, and P. Kierulf 1996. Different binding of 125I-LPS to plasma proteins from persons with high or low HDL. Scand. J. Clin. Lab. Invest. 56:533543.

Emmanuel, D. G. V., K. L. Madsen, T. A. Churchill, S. M. Dunn, and B. N. Ametaj. 2007. Acidosis and lipopolysaccharide from Escherichia coli 055:B5 cause hyperpermeability of rumen and colon tissues. J. Dairy Sci. 90:5552-5557.

Emmanuel, D. G. V., S. Shanthipoosan, and B. N. Ametaj. 2010. High grain diets perturb rumen and plasma metabolites and induce inflammatory responses in early lactation dairy cows. Ital. J. Anim. Sci. 6:424-426.

Endo, H., M. Niioka, N. Kobayashi, M. Tanaka, and T. Watanabe. 2013. Butyrate-producing probiotics reduce nonalcoholic fatty liver disease progression in rats: new insight into the probiotics for the gut-liver axis. PLoS ONE 8:e63388.

Erridge, C., E. Bennett-Guerrero, and I. R. Poxton. 2002. Structure and function of lipopolysaccharides. Microbes Infect. 4:837-851.

Feingold, K. R., J. L. Funk, A. H. Moser, J. K. Shigenaga, J. H. Rapp, and C. Grunfeld. 1995. Role for circulating lipoproteins in protection from endotoxin toxicity. Infect. Immun. 63:2041-2046.

Feingold, K. R., and C. Grunfeld. 2011. The role of HDL in innate immunity. J. Lipid Res. 52:1-3.

Ferreri, L. F., and R. C. Elbein. 1982. Fractionation of plasma triglyceride-rich lipoproteins of the dairy cow: evidence of chylomicronsize particles. J. Dairy Sci. 65:1912-1920.

Fischer, M. B., A. P. Prodeus, A. Nicholson-Weller, M. Ma, J. Murrow, R. R. Reid, H. B. Warren, A. L. Lage, F. D. Moore, and F. S. Rosen. 1997. Increased susceptibility to endotoxin shock in complement C3-and C4-deficient mice is corrected by $\mathrm{C} 1$ inhibitor replacement. J. Immunol. 159:976-982.

Flierl, M. A., D. Rittirsch, B. A. Nadeau, D. E. Day, F. S. Zetoune, J. V. Sarma, M. S. Huber-Lang, and P. A. Ward. 2008. Functions of the complement components C3 and C5 during sepsis. FASEB J. 22:3483-3490.

Galanos, C., and O. Luderitz. 1976. The role of the physical state of lipopolysaccharides in the interaction with complement. Eur. J. Biochem. 65:403-408

Ganz, M., T. Csak, B. Nath, and G. Szabo. 2011. Lipopolysaccharide induces and activates the Nalp3 inflammasome in the liver. World J. Gastroenterol. 17:4772-4778.

Garner, M. R., J. F. Flint, and J. B. Russell. 2002. Allisonella histaminiformans gen. nov., sp. nov. A novel bacterium that produces histamine, utilizes histidine as its sole energy source, and could play a role in bovine and equine laminitis. Syst. Appl. Microbiol. $25: 498-506$.

Ghoshal, S., J. Witta, J. Zhong, W. de Villiers, and E. Eckhardt. 2009. Chylomicrons promote intestinal absorption of lipopolysaccharides. J. Lipid Res. 50:90-97.

Gilbert, F. B., P. Cunha, K. Jensen, E. J. Glass, G. Foucras, C. Robert-Granie, R. Rupp, and P. Rainard. 2013. Differential response of bovine mammary epithelial cells to Staphylococcus aureus or Escherichia coli agonists of the innate immune system. Vet. Res. 44:40.

Gilbert, R. O., S. T. Shin, C. L. Guard, H. N. Erb, and M. Frajblat. 2005. Prevalence of endometritis and its effects on reproductive performance of dairy cows. Theriogenology 64:1879-1888.

Ginsburg, I. 2002. Role of lipoteichoic acid in infection and inflammation. Lancet Infect. Dis. 2:171-179.

Goldammer, T. H. Zerbe, A. Molenaar, H. J. Schuberth, R. M. Brunner, S. R. Kata, and H. M. Seyfert. 2004. Mastitis increases mammary mRNA abundance of beta-defensin 5, toll-like-receptor 2 (TLR2), and TLR4 but not TLR9 in cattle. Clin. Diagn. Lab. Immunol. 11:174-185.

Government of Canada. 2014. Culling and Replacement Rates in Dairy Herds in Canada. Ottawa, ON, Canada. Accessed Apr. 29, 2016. http://www.dairyinfo.gc.ca/index_e.php?s1=dff-fcil\&s2=mrrpcle\&s $3=$ cr-tr.
Goyert, S. M., and E. Ferrero. 1987. Biochemical analysis of myeloid antigens and cDNA expression of gp55 (CD14). Pages 613-618 in Leukocyte Typing III. A. J. McMichael, P. C. L. Berkley and S. Cobbold, ed. Springer-Verlag, New York, NY.

Gozho, G. N., J. C. Plaizier, D. O. Krause, A. D. Kennedy, and K. M. Wittenberg. 2005. Subacute ruminal acidosis induces ruminal lipopolysaccharide endotoxin release and triggers an inflammatory response. J. Dairy Sci. 88:1399-1403.

Gray, C. P., T. D. St George, and N. N. Jonsson. 2007. Milk fever in dairy cattle: A novel hypothesis for an immune mediated aetiology. Cattle Pract. 15:277-282.

Grummer, R. R. 2008. Nutritional and management strategies for the prevention of fatty liver in dairy cattle. Vet. J. 176:10-20.

Grunfeld, C., and K. R. Feingold. 2009. Endotoxin in the gut and chylomicrons: Translocation or transportation? J. Lipid Res. 50:1-2.

Guo, S., R. Al-Sadi, H. M. Said, and T. Y. Ma. 2013. Lipopolysaccharide causes an increase in intestinal tight junction permeability in vitro and in vivo by inducing enterocyte membrane expression and localization of TLR-4 and CD14. Am. J. Pathol. 182:375-387.

Hailman, E., H. S. Lichenstein, M. M. Wurfel, D. S. Miller, D. A Johnson, M. Kelley, L. A. Busse, M. M. Zukowski, and S. D. Wright. 1994. Lipopolysaccharide (LPS)-binding protein accelerates the binding of LPS to CD14. J. Exp. Med. 179:269-277.

Hakogi, E., H. Tamura, S. Tanaka, A. Kohata, Y. Shimada, and K. Tabuchi. 1989. Endotoxin levels in milk and plasma of mastitisaffected cows measured with a chromogenic limulus test. Vet. Microbiol. 20:267-274.

Hamadani, H., A. A. Khan, M. T. Banday, I. Ashraf, N. Handoo, A. B. Shah, and A. Hamadani. 2013. Bovine mastitis-A disease of serious concern for dairy farmers. Int. J. Livest. Res. 3:42-55.

Han, X., M. P. Fink, R. Yang, and R. L. Delude. 2004. Increased iNOS activity is essential for intestinal epithelial tight junction dysfunction in endotoxemic mice. Shock 21:261-270.

Herath, S., S. T. Lilly, D. P. Fischer, E. J. Williams, H. Dobson, C. E. Bryant, and I. M. Sheldon. 2009. Bacterial lipopolysaccharide induces an endocrine switch from prostaglandin F2 $\alpha$ to prostaglandin E2 in bovine endometrium. Endocrinology 150:1912-1920.

Herath, S., E. J. Williams, S. T. Lilly, R. O. Gilbert, H. Dobson, C. E. Bryant, and I. M. Sheldon. 2007. Ovarian follicular cells have innate immune capabilities that modulate their endocrine function. Reproduction 134:683-693.

Herzog, K., K. Strüve, J. P. Kastelic, M. Piechotta, S. E. Ulbrich, C. Pfarrer, K. Shirasuna, T. Shimizu, A. Miyamoto, and H. Bollwein. 2012. Escherichia coli lipopolysaccharide administration transiently suppresses luteal structure and function in diestrous cows. Reproduction 144:467-476.

Holowaychuk, M. K., B. D. Hansen, T. C. DeFrancesco, and S. L. Marks. 2009. Ionized hypocalcemia in critically ill dogs. J. Vet. Intern. Med. 23:509-513.

Hotchkiss, R. S., and I. E. Karl. 1996. Calcium: A regulator of the inflammatory response in endotoxemia and sepsis. New Horiz. 4:58-71.

Huber-Lang, M. S., J. V. Sarma, S. R. McGuire, K. T. Lu, R. F. Guo, V. A. Padgaonkar, E. M. Younkin, I. J. Laudes, N. C. Riedemann, J. G. Younger, and P. A. Ward. 2001. Protective effects of anti-C5a peptide antibodies in experimental sepsis. FASEB J. 15:568-570.

Ibeagha-Awemu, E. M., J. W. Lee, A. E. Ibeagha, D. D. Bannerman, M. J. Paape, and X. Zhao. 2008. Bacterial lipopolysaccharide induces increased expression of toll-like receptor (TLR) 4 and downstream TLR signaling molecules in bovine mammary epithelial cells. Vet. Res. 39:21.

Jacobsen, S., T. Toelboell, and P. H. Andersen. 2005. Dose dependency and individual variability in selected clinical, haematological and blood biochemical responses after systemic lipopolysaccharide challenge in cattle. Vet. Res. 36:167-178.

Jing, L., R. Zhang, Y. Liu, W. Zhu, and S. Mao. 2014. Intravenous lipopolysaccharide challenge alters ruminal bacterial microbiota and disrupts ruminal metabolism in dairy cattle. Br. J. Nutr. 112:170-182.

Jørgensen, H. B., B. Buitenhuis, C. M. Rontved, L. Jiang, K. L. Ingvartsen, and P. Sorensen. 2012. Transcriptional profiling of the 
bovine hepatic response to experimentally induced E. coli mastitis. Physiol. Genomics 44:595-606.

Kalter, E. S., W. C. van Dijk, A. Timmerman, J. Verhoef, and B. N. Bouma. 1983. Activation of purified human plasma prekallikrein triggered by cell wall fractions of Escherichia coli and Staphylococcus aureus. J. Infect. Dis. 148:682-691.

Kaze, C., M. Mevissen, G. Hirsbrunner, and A. Steiner. 2004. Effect of endotoxins on contractility of smooth muscle preparations from the bovine abomasal antrum. Dtsch. Tierarztl. Wochenschr. 111:28-35.

Kerro Dego, O., J. E. van Dijk, and H. Nederbragt. 2002. Factors involved in the early pathogenesis of bovine Staphylococcus aureus mastitis with emphasis on bacterial adhesion and invasion. A review. Vet. Q. 24:181-198.

Khafipour, E., D. O. Krause, and J. C. Plaizier. 2009a. Alfalfa pelletinduced subacute ruminal acidosis in dairy cows increases bacterial endotoxin in the rumen without causing inflammation. J. Dairy Sci. 92:1712-1724

Khafipour, E., D. O. Krause, and J. C. Plaizier. 2009b. A grain-based subacute ruminal acidosis challenge causes translocation of lipopolysaccharide and triggers inflammation. J. Dairy Sci. 92:10601070.

Khafipour, E., S. Li, J. C. Plaizier, and D. O. Krause. 2009c. Rumen microbiome composition determined using two nutritional models of subacute ruminal acidosis. Appl. Environ. Microbiol. 75:7115-7124.

Khare, S., N. Luc, A. Dorfleutner, and C. Stehlik. 2010. Inflammasomes and their activation. Crit. Rev. Immunol. 30:463-487.

Khovidhunkit, W., R. A. Memon, K. R. Feingold, and C. Grunfeld. 2000. Infection and inflammation-induced proatherogenic changes of lipoproteins. J. Infect. Dis. 181:S462-S472.

Kimura, K., J. P. Goff, M. E. Kehrli Jr., and T. A. Reinhardt. 2002. Decreased neutrophil function as a cause of retained placenta in dairy cattle. J. Dairy Sci. 85:544-550.

Kitchens, R. L., G. Wolfbauer, J. J. Albers, and R. S. Munford. 1999. Plasma lipoproteins promote the release of bacterial lipopolysaccharide from the monocyte cell surface. J. Biol. Chem. 274:3411634122.

Knirel, Y. A., and M. A. Valvano. 2011. Bacterial Lipopolysaccharides: Structure, Chemical Synthesis, Biogenesis and Interaction with Host Cells. Springer, Berlin, Germany.

Korhonen, R., R. Korpela, and E. Moilanen. 2002. Signalling mechanisms involved in the induction of inducible nitric oxide synthase by Lactobacillus rhamnosus GG, endotoxin, and lipoteichoic acid. Inflammation 26:207-214.

Krause, K. M., and G. R. Oetzel. 2006. Understanding and preventing subacute ruminal acidosis in dairy herds: A review. Anim. Feed Sci. Technol. 126:215-236.

Ladenson, J. H., and J. C. Shyong. 1977. Influence of fatty acids on the binding of calcium to human serum albumin. Clin. Chim. Acta 75:293-302.

Lassman, B. A. 1980. Release of endotoxin from rumen bacteria and endotoxin absorption from the rumen. MS Thesis. Kansas State Univ., Manhattan.

Lavon, Y., G. Leitner, U. Moallem, E. Klipper, H. Voet, S. Jacoby, G. Glick, R. Meidan, and D. Wolfenson. 2011. Immediate and carryover effects of Gram-negative and Gram-positive toxin-induced mastitis on follicular function in dairy cows. Theriogenology 76:942-953.

LeBlanc, S. J. 2008. Postpartum uterine disease and dairy herd reproductive performance: A review. Vet. J. 176:102-114.

LeBlanc, S. J., K. E. Leslie, and T. F. Duffield. 2005. Metabolic predictors of displaced abomasum in dairy cattle. J. Dairy Sci. 88:159-170.

Levine, D. M., T. S. Parker, T. M. Donnelly, A. Walsh, and A. L. Rubin. 1993. In vivo protection against endotoxin by plasma high density lipoprotein. Proc. Natl. Acad. Sci. USA 90:12040-12044.

Li, S., E. Khafipour, D. O. Krause, A. Kroeker, J. C. RodriguezLecompte, G. N. Gozho, and J. C. Plaizier. 2012. Effects of subacute ruminal acidosis challenges on fermentation and endotoxins in the rumen and hindgut of dairy cows. J. Dairy Sci. 95:294-303.
Littledike, E. T., S. C. Whipp, D. A. Witzel, and A. L. Baetz. 1970. Insulin, corticoids, and parturient paresis. Pages 165-176 in Parturient Hypocalcemia. J. J. B. Anderson, ed. Academic Press, New York, NY.

Lüttgenau, J., K. Herzog, K. Strüve, S. Latter, A. Boos, R. M. Bruckmaier, H. Bollwein, and M. P. Kowalewski. 2016. LPS-mediated effects and spatio-temporal expression of TLR2 and TLR4 in the bovine corpus luteum. Reproduction 151:391-399.

Magata, F., M. Horiuchi, A. Miyamoto, and T. Shimizu. 2014. Peptidoglycan inhibits progesterone and androstenedione production in bovine ovarian theca cells. Toxicol. In Vitro 28:961-967.

Malcolm, D. S., G. P. Zaloga, and J. W. Holaday. 1989. Calcium administration increases the mortality of endotoxic shock in rats. Crit. Care Med. 17:900-903.

Mallard, B. A., J. C. Dekkers, M. J. Ireland, K. E. Leslie, S. Sharif, C. Lacey Vankampen, L. Wagter, and B. N. Wilkie. 1998. Alteration in immune responsiveness during the peripartum period and its ramification on dairy cow and calf health. J. Dairy Sci. 81:585-595.

Mani, V., T. E. Weber, L. H. Baumgard, and N. K. Gabler. 2012 Growth and development symposium: Endotoxin, inflammation, and intestinal function in livestock. J. Anim. Sci. 90:1452-1465.

Manikis, P., S. Jankowski, H. Zhang, R. J. Kahn, and J. L. Vincent. 1995. Correlation of serial blood lactate levels to organ failure and mortality after trauma. Am. J. Emerg. Med. 13:619-622.

Mao, S. Y., R. Y. Zhang, D. S. Wang, and W. Y. Zhu. 2013. Impact of subacute ruminal acidosis (SARA) adaptation on rumen microbiota in dairy cattle using pyrosequencing. Anaerobe 24:12-19.

Mashburn-Warren, L., R. J. McLean, and M. Whiteley. 2008. Gramnegative outer membrane vesicles: Beyond the cell surface. Geobiology 6:214-219.

Mateus, L., L. Lopes da Costa, P. Diniz, and A. J. Ziecik. 2003. Relationship between endotoxin and prostaglandin (PGE2 and PGFM) concentrations and ovarian function in dairy cows with puerperal endometritis. Anim. Reprod. Sci. 76:143-154.

Meissner, H. H., P. H. Henning, C. H. Horn, K.-J. Leeuw, F. M. Hagg, and G. Fouché. 2010. Ruminal acidosis: A review with detailed reference to the controlling agent Megasphaera elsdenii NCIMB 41125. S. Afr. J. Anim. Sci. 40:79-100.

Melendez, P., J. Bartolome, L. F. Archbald, and A. Donovan. 2003. The association between lameness, ovarian cysts and fertility in lactating dairy cows. Theriogenology 59:927-937.

Mikkelsen, M. E., A. N. Miltiades, D. F. Gaieski, M. Goyal, B. D. Fuchs, C. V. Shah, S. L. Bellamy, and J. D. Christie. 2009. Serum lactate is associated with mortality in severe sepsis independent of organ failure and shock. Crit. Care Med. 37:1670-1677.

Minuti, A., S. Ahmed, E. Trevisi, F. Piccioli-Cappelli, G. Bertoni, N. Jahan, and P. Bani. 2014. Experimental acute rumen acidosis in sheep: Consequences on clinical, rumen, and gastrointestinal permeability conditions and blood chemistry. J. Anim. Sci. 92:3966-3977.

Minuti, A., A. Palladino, M. J. Khan, S. Alqarni, A. Agrawal, F. Piccioli-Capelli, F. Hidalgo, F. C. Cardoso, E. Trevisi, and J. J. Loor. 2015. Abundance of ruminal bacteria, epithelial gene expression, and systemic biomarkers of metabolism and inflammation are altered during the peripartal period in dairy cows. J. Dairy Sci. 98:8940-8951.

Mitchell, J. A., M. J. Paul-Clark, G. W. Clarke, S. K. McMaster, and N. Cartwright. 2007. Critical role of toll-like receptors and nucleotide oligomerisation domain in the regulation of health and disease. J. Endocrinol. 193:323-330.

Miyake, K. 2007. Innate immune sensing of pathogens and danger signals by cell surface Toll-like receptors. Semin. Immunol. 19:3-10.

Morath, S., S. von Aulock, and T. Hartung. 2005. Structure/function relationships of lipoteichoic acids. J. Endotoxin Res. 11:348-356.

More, J., and M. Bulmer. 2013. Human serum albumin: A multifunctional plasma protein. Pages 159-183 in Production of Plasma Proteins for Therapeutic Use. J. Bertolini, N. Goss, and J. Curling, ed. Wiley and Sons Inc., Hoboken, NJ.

Moreira, A. P., T. F. Texeira, A. B. Ferreira, C. Peluzio Mdo, and C. Alfenas Rde. 2012. Influence of a high-fat diet on gut microbiota, 
intestinal permeability and metabolic endotoxaemia. Br. J. Nutr. 108:801-809.

Morrison, D. C., and C. G. Cochrane. 1974. Direct evidence for Hageman factor (factor XII) activation by bacterial lipopolysaccharides (endotoxins). J. Exp. Med. 140:797-811.

Morrison, D. C., and L. F. Kline. 1977. Activation of the classical and properdin pathways of complement by bacterial lipopolysaccharides (LPS). J. Immunol. 118:362-368.

Munford, R. S., and J. M. Dietschy. 1985. Effects of specific antibodies, hormones, and lipoproteins on bacterial lipopolysaccharides injected into the rat. J. Infect. Dis. 152:177-184.

Munford, R. S., C. L. Hall, and J. M. Dietschy. 1981. Binding of Salmonella typhimurium lipopolysaccharides to rat high-density lipoproteins. Infect. Immun. 34:835-843.

Munford, R. S. 2005. Detoxifying endotoxin: Time, place and person. J. Endotoxin Res. 11:69-84.

Neal, M. D., C. Leaphart, R. Levy, J. Prince, T. R. Billiar, S. Watkins, J. Li, S. Cetin, H. Ford, A. Schreiber, and D. J. Hackam. 2006. Enterocyte TLR4 mediates phagocytosis and translocation of bacteria across the intestinal barrier. J. Immunol. 176:3070-3079.

Netea, M. G., M. van Deuren, B. J. Kullberg, J. M. Cavaillon, and J. W. Van der Meer. 2002. Does the shape of lipid A determine the interaction of LPS with Toll-like receptors? Trends Immunol. $23: 135-139$.

Neutra, M. R., and P. A. Kozlowski. 2006. Mucosal vaccines: The promise and the challenge. Nat. Rev. Immunol. 6:148-158.

Nilsen, N. J., S. Deininger, U. Nonstad, F. Skjeldal, H. Husebye, D. Rodionov, S. von Aulock, T. Hartung, E. Lien, O. Bakke, and T. Espevik. 2008. Cellular trafficking of lipoteichoic acid and Toll-like receptor 2 in relation to signaling: Role of CD14 and CD36. J. Leukoc. Biol. 84:280-291.

Nocek, J. E. 1997. Bovine acidosis: Implications on laminitis. J. Dairy Sci. 80:1005-1028.

Nolan, J. P. 1981. Endotoxin, reticuloendothelial function, and liver injury. Hepatology 1:458-465.

Ohtsuka, H., K. Ohki, M. Tajima, T. Yoshino, and K. Takahashi. 1997. Evaluation of blood acid-base balance after experimental administration of endotoxin in adult cow. J. Vet. Med. Sci. 59:483-485.

Overton, T. R., and M. R. Waldron. 2004. Nutritional management of transition dairy cows: Strategies to optimize metabolic health. J. Dairy Sci. 87:E105-E119.

Percy, M. G., and A. Grundling. 2014. Lipoteichoic acid synthesis and function in gram-positive bacteria. Annu. Rev. Microbiol. 68:81-100

Peter, A. T., W. T. Bosu, and R. O. Gilbert. 1990. Absorption of Escherichia coli endotoxin (lipopolysaccharide) from the uteri of postpartum dairy cows. Theriogenology 33:1011-1014.

Pietrocola, G., C. R. Arciola, S. Rindi, A. Di Poto, A. Missineo, L. Montanaro, and P. Speziale. 2011. Toll-like receptors (TLRs) in innate immune defense against Staphylococcus aureus. Int. J. Artif. Organs 34:799-810

Plaizier, J. C., E. Khafipour, S. Li, G. N. Gozho, and D. O. Krause, 2012. Subacute ruminal acidosis (SARA), endotoxins and health consequences. Anim. Feed Sci. Technol. 17:9-21.

Plaizier, J. C., S. Li, M. Le Sciellour, B. L. Schurmann, P. Gorka, and G. B. Penner. 2014. Effects of duration of moderate increases in grain feeding on endotoxins in the digestive tract and acute phase proteins in peripheral blood of yearling calves. J. Dairy Sci. 97:7076-7084.

Potoka, D. A., E. P. Nadler, J. S. Upperman, and H. R. Ford. 2002. Role of nitric oxide and peroxynitrite in gut barrier failure. World J. Surg. 26:806-811.

Price, J. C., J. J. Bromfield, and I. M. Sheldon. 2013. Pathogenassociated molecular patterns initiate inflammation and perturb the endocrine function of bovine granulosa cells from ovarian dominant follicles via TLR2 and TLR4 pathways. Endocrinology 154:3377-3386.

Ravin, H. A., D. Rowley, C. Jenkins, and J. Fine. 1960. On the absorption of bacterial endotoxin from the gastro-intestinal tract of the normal and shocked animal. J. Exp. Med. 112:783-792.
Quezado, Z. M., W. D. Hoffman, J. A. Winkelstein, I. Yatsiv, C. A Koev, L. C. Cork, R. J. Elin, P. Q. Eichacker, and C. Natanson. 1994. The third component of complement protects against Escherichia coli endotoxin-induced shock and multiple organ failure. J. Exp. Med. 179:569-578.

Rainard, P., and C. Riollet. 2006. Innate immunity of the bovine mammary gland. Vet. Res. 37:369-400.

Ramadori, G., and B. Christ. 1999. Cytokines and the hepatic acutephase response. Semin. Liver Dis. 19:141-155.

Read, T. E., H. W. Harris, C. Grunfeld, K. R. Feingold, M. C. Calhoun, J. P. Kane, and J. H. Rapp. 1993a. Chylomicrons enhance endotoxin excretion in bile. Infect. Immun. 61:3496-3502.

Read, T. E., H. W. Harris, C. Grunfeld, K. R. Feingold, J. P. Kane, and J. H. Rapp. 1993b. The protective effect of serum lipoproteins against bacterial lipopolysaccharide. Eur. Heart J. 14:125-129.

Reisinger, N., S. Schaumberger, V. Nagl, S. Hessenberger, and G. Schatzmayr. 2015. Concentration dependent influence of lipopolysaccharides on separation of hoof Explants and supernatant lactic acid concentration in an ex vivo/in vitro laminitis model. PLoS ONE 10:e0143754.

Ritze, Y., G. Bárdos, A. Claus, V. Ehrmann, I. Bergheim, A. Schwiertz, and S. C. Bischoff. 2014. Lactobacillus rhamnosus GG protects against non-alcoholic fatty liver disease in mice. PLoS ONE 9:e80169.

Rosen, F. S., R. C. Skarnes, M. Landy, and M. J. Shear. 1958. Inactivation of endotoxin by a humoral component. III. Role of divalent cation and a dialyzable component. J. Exp. Med. 108:701-711.

Saleem, F., B. N. Ametaj, S. Bouatra, R. Mandal, Q. Zebeli, S. M. Dunn, and D. S. Wishart. 2012. A metabolomics approach to uncover the effects of grain diets on rumen health in dairy cows. J. Dairy Sci. 95:6606-6623.

Saleem, F., S. Bouatra, A. C. Guo, N. Psychogios, R. Mandal, S. M. Dunn, B. N. Ametaj, and D. S. Wishart. 2013. The bovine ruminal fluid metabolome. Metabolomics 9:360-378.

Scholz, W., M. R. McClurg, G. J. Cardenas, M. Smith, D. J. Noonan, T. E. Hugli, and E. L. Morgan. 1990. C5a-mediated release of interleukin 6 by human monocytes. Clin. Immunol. Immunopathol. 57:297-307.

Schröder, N. W., S. Morath, C. Alexander, L. Hamann, T. Hartung, U. Zahringer, U. B. Gobel, J. R. Weber, and R. R. Schumann. 2003. Lipoteichoic acid (LTA) of Streptococcus pneumoniae and Staphcoccus aureuylos activates immune cells via Toll-like receptor (TLR)-2, lipopolysaccharide-binding protein (LBP), and CD14, whereas TLR-4 and MD-2 are not involved. J. Biol. Chem. 278:15587-15594.

Seeley, E. J., M. A. Matthay, and P. J. Wolters. 2012. Inflection points in sepsis biology: From local defense to systemic organ injury. Am. J. Physiol. Lung Cell. Mol. Physiol. 303:L355-L363.

Sharma, R., S. von Haehling, M. Rauchhaus, A. P. Bolger, S. GenthZotz, W. Doehner, B. Oliver, P. A. Poole-Wilson, H. D. Volk, A. J. Coats, I. M. Adcock, and S. D. Anker. 2005. Whole blood endotoxin responsiveness in patients with chronic heart failure: the importance of serum lipoproteins. Eur. J. Heart Fail. 7:479-484

Shaver, R. D. 1997. Nutritional risk factors in the etiology of left displaced abomasum in dairy cows: A review. J. Dairy Sci. 80:24492453.

Sheldon, I. M., J. Cronin, L. Goetze, G. Donofrio, and H. J. Schuberth. 2009a. Defining postpartum uterine disease and the mechanisms of infection and immunity in the female reproductive tract in cattle. Biol. Reprod. 81:1025-1032.

Sheldon, I. M., and H. Dobson. 2004. Postpartum uterine health in cattle. Anim. Reprod. Sci. 82-83:295-306.

Sheldon, I. M., D. E. Noakes, A. N. Rycroft, D. U. Pfeiffer, and H. Dobson. 2002. Influence of uterine bacterial contamination after parturition on ovarian dominant follicle selection and follicle growth and function in cattle. Reproduction 123:837-845.

Sheldon, I. M., S. B. Price, J. Cronin, R. O. Gilbert, and J. E. Gadsby. 2009b. Mechanisms of infertility associated with clinical and subclinical endometritis in high producing dairy cattle. Reprod. Domest. Anim. 44:1-9. 
Singh, A. K., Y. Jiang, and S. Gupta. 2007. Effects of bacterial toxins on endothelial tight junction in vitro: A mechanism-based investigation. Toxicol. Mech. Methods 17:331-347.

Singh, S. S., R. D. Murray, and W. R. Ward. 1994. Gross and histopathological study of endotoxin-induced hoof lesions in cattle. J. Comp. Pathol. 110:103-115.

Skarnes, R. C., and L. C. Chedid. 1964. Biological degradation and inactivation of endotoxin (chromate-labeled). Pages 575-587 in Bacterial Endotoxins. M. Landy and W. Braun, ed. Rutgers University Press, New Brunswick, NJ.

Skarnes, R. C. 1966. The inactivation of endotoxin after interaction with certain proteins of normal serum. Ann. N. Y. Acad. Sci. 133:644-662.

Slama, H., D. Vaillancourt, and A. K. Goff. 1994. Effect of bacterial cell wall and lipopolysaccharide on arachidonic acid metabolism by caruncular and allantochorionic tissues from cows that calved normally and those that retained fetal membranes. Theriogenology 41:923-942.

Steele, M. A., J. Croom, M. Kahler, O. AlZahal, S. E. Hook, K. Plaizier, and B. W. McBride. 2011. Bovine rumen epithelium undergoes rapid structural adaptations during grain-induced subacute ruminal acidosis. Am. J. Physiol. Regul. Integr. Comp. Physiol. 300:R1515-R1523.

Steiger, M., M. Senn, G. Altreuther, D. Werling, F. Sutter, M. Kreuzer, and W. Langhans. 1999. Effect of a prolonged low-dose lipopolysaccharide infusion on feed intake and metabolism in heifers. J. Anim. Sci. 77:2523-2532.

Stelter, F., S. Witt, B. Furll, R. S. Jack, T. Hartung, and C. Schutt. 1998. Different efficacy of soluble CD14 treatment in high-and lowdose LPS models. Eur. J. Clin. Invest. 28:205-213.

Stengärde, L., K. Holtenius, M. Traven, J. Hultgren, R. Niskanen, and U. Emanuelson. 2010. Blood profiles in dairy cows with displaced abomasum. J. Dairy Sci. 93:4691-4699.

Stevens, J. B., and W. G. Olson. 1984. Free fatty acid-induced hypocalcemia in food-deprived dairy cattle. Am. J. Vet. Res. 45:24482450 .

Strandberg, Y., C. Gray, T. Vuocolo, L. Donaldson, M. Broadway, and R. Tellam. 2005. Lipopolysaccharide and lipoteichoic acid induce different innate immune responses in bovine mammary epithelial cells. Cytokine 31:72-86.

Sugita, T., C. C. Huang, and M. Abramson. 1986. Effect of endotoxin on keratin production of keratinocytes in vitro. Am. J. Otolaryngol. 7:42-46.

Suzuki, C., K. Yoshioka, S. Iwamura, and H. Hirose. 2001. Endotoxin induces delayed ovulation following endocrine aberration during the proestrous phase in Holstein heifers. Domest. Anim. Endocrinol. 20:267-278.

Tajima, K., R. I. Aminov, T. Nagamine, H. Matsui, M. Nakamura, and Y. Benno. 2001. Diet-dependent shifts in the bacterial population of the rumen revealed with real-time PCR. Appl. Environ. Microbiol. $67: 2766-2774$.

Tate, W. J., 3rd, H. Douglas, A. I. Braude, and W. W. Wells. 1966. Protection against lethality of E. coli endotoxin with "O" antiserum. Ann. N. Y. Acad. Sci. 133:746-762.

Thaveeratitham, P., W. Khovidhunkit, and S. Patumraj. 2007. Highdensity lipoproteins (HDL) inhibit endotoxin-induced leukocyte adhesion on endothelial cells in rats: effect of the acute-phase HDL. Clin. Hemorheol. Microcirc. 36:1-12.

Tobias, P. S., K. Soldau, and R. J. Ulevitch. 1989. Identification of a lipid A binding site in the acute phase reactant lipopolysaccharide binding protein. J. Biol. Chem. 264:10867-10871.

Toffaletti, J., and B. Abrams. 1989. Effects of in vivo and in vitro production of lactic acid on ionized, protein-bound, and complexbound calcium in blood. Clin. Chem. 35:935-938.

Toribio, R. E., C. W. Kohn, J. Hardy, and T. J. Rosol. 2005. Alterations in serum parathyroid hormone and electrolyte concentrations and urinary excretion of electrolytes in horses with induced endotoxemia. J. Vet. Intern. Med. 19:223-231.

Tran-Dinh, A., D. Diallo, S. Delbosc, L. M. Varela-Perez, Q. B. Dang, B. Lapergue, E. Burillo, J. B. Michel, A. Levoye, J. L. Martin-
Ventura, and O. Meilhac. 2013. HDL and endothelial protection. Br. J. Pharmacol. 169:493-511.

Trebicka, J., A. Krag, S. Gansweid, B. Appenrodt, P. Schiedermaier, T. Sauerbruch, and U. Spengler. 2011. Endotoxin and tumor necrosis factor-receptor levels in portal and hepatic vein of patients with alcoholic liver cirrhosis receiving elective transjugular intrahepatic portosystemic shunt. Eur. J. Gastroenterol. Hepatol. $23: 1218-1225$.

Tso, P., and J. A. Balint. 1986. Formation and transport of chylomicrons by enterocytes to the lymphatics. Am. J. Physiol. 250:G715G726

Turner, M. L., J. G. Cronin, G. D. Healey, and I. M. Sheldon. 2014. Epithelial and stromal cells of bovine endometrium have roles in innate immunity and initiate inflammatory responses to bacterial lipopeptides in vitro via Toll-like receptors TLR2, TLR1, and TLR6. Endocrinology 155:1453-1465.

Turner, M. L., G. D. Healey, and I. M. Sheldon. 2012. Immunity and inflammation in the uterus. Reprod. Domest. Anim. 47(Suppl. 4):402-409.

Van Amersfoort, E. S., T. J. Van Berkel, and J. Kuiper. 2003. Receptors, mediators, and mechanisms involved in bacterial sepsis and septic shock. Clin. Microbiol. Rev. 16:379-414.

van Miert, A. S., L. E. Van Der Wal-Komproe, and C. T. Van Duin. 1977. Effects of antipyretic agents on fever and ruminal stasis induced by endotoxins in conscious goats. Arch. Int. Pharmacodyn. Ther. 225:39-50.

Viktorov, A. V., and V. A. Iurkiv. 2006. Binding of lipopolysaccharide and complexes of lipopolysaccharide with serum low density lipoproteins to liver macrophages. Biomed. Khim. 52:36-43.

Vishnyakova, T. G., A. V. Bocharov, I. N. Baranova, Z. Chen, A. T. Remaley, G. Csako, T. L. Eggerman, and A. P. Patterson. 2003. Binding and internalization of lipopolysaccharide by Cla-1, a human orthologue of rodent scavenger receptor B1. J. Biol. Chem. 278:22771-22780.

Vlaminck, K., H. van Meirhaeghe, C. van den Hende, W. Oyaert, and E. Muylle. 1985. Effect of endotoxins on abomasal emptying in cattle. Dtsch. Tierarztl. Wochenschr. 92:392-395.

Wagner, J. G., and R. A. Roth. 1999. Neutrophil migration during endotoxemia. J. Leukoc. Biol. 66:10-24.

Waldron, M. R., B. J. Nonnecke, T. Nishida, R. L. Horst, and T. R. Overton. 2003. Effect of lipopolysaccharide infusion on serum macromineral and vitamin D concentrations in dairy cows. J. Dairy Sci. 86:3440-3446.

Werling, D., F. Sutter, M. Arnold, G. Kun, P. C. J. Tooten, E. Gruys, M. Kreuzer, and W. Langhans. 1996. Characterisation of the acute phase response of heifers to a prolonged low dose infusion of lipopolysaccharide. Res. Vet. Sci. 61:252-257.

Whitsett, J., and R. C. Tsang. 1977. In vitro effects of fatty acids on serum-ionized calcium. J. Pediatr. 91:233-236.

Wiersinga, W. J., S. J. Leopold, D. R. Cranendonk, and T. van der Poll. 2014. Host innate immune responses to sepsis. Virulence $5: 36-44$.

Williams, E. J., D. P. Fischer, D. E. Noakes, G. C. England, A. Rycroft, H. Dobson, and I. M. Sheldon. 2007. The relationship between uterine pathogen growth density and ovarian function in the postpartum dairy cow. Theriogenology 68:549-559.

Williams, E. J., S. Herath, G. C. England, H. Dobson, C. E. Bryant, and I. M. Sheldon. 2008. Effect of Escherichia coli infection of the bovine uterus from the whole animal to the cell. Animal $2: 1153-1157$

Williams, J. M., C. A. Duckworth, A. J. Watson, M. R. Frey, J. C. Miguel, M. D. Burkitt, R. Sutton, K. R. Hughes, L. J. Hall, J. H. Caamano, B. J. Campbell, and D. M. Pritchard. 2013. A mouse model of pathological small intestinal epithelial cell apoptosis and shedding induced by systemic administration of lipopolysaccharide. Dis. Model. Mech. 6:1388-1399.

Wittek, T., M. Furll, and P. D. Constable. 2004. Prevalence of endotoxemia in healthy postparturient dairy cows and cows with abomasal volvulus or left displaced abomasum. J. Vet. Intern. Med. 18:574-580. 
Woclawek-Potocka, I., K. Deptula, M. M. Bah, H. Y. Lee, K. Okuda, and D. J. Skarzynski. 2004. Effects of nitric oxide and tumor necrosis factor-alpha on production of prostaglandin F2alpha and E2 in bovine endometrial cells. J. Reprod. Dev. 50:333-340.

Wright, S. D., R. A. Ramos, P. S. Tobias, R. J. Ulevitch, and J. C. Mathison. 1990. CD14, a receptor for complexes of lipopolysaccharide (LPS) and LPS binding protein. Science 249:1431-1433.

Wright, S. D., P. S. Tobias, R. J. Ulevitch, and R. A. Ramos. 1989. Lipopolysaccharide (LPS) binding protein opsonizes LPS-bearing particles for recognition by a novel receptor on macrophages. J. Exp. Med. 170:1231-1241.

Wu, A., C. J. Hinds, and C. Thiemermann. 2004. High-density lipoproteins in sepsis and septic shock: Metabolism, actions, and therapeutic applications. Shock 21:210-221.

Wurfel, M. M., E. Hailman, and S. D. Wright. 1995. Soluble CD14 acts as a shuttle in the neutralization of lipopolysaccharide (LPS) by LPS-binding protein and reconstituted high density lipoprotein. J. Exp. Med. 181:1743-1754.

Wurfel, M. M., S. T. Kunitake, H. Lichenstein, J. P. Kane, and S. D. Wright. 1994. Lipopolysaccharide (LPS)-binding protein is carried on lipoproteins and acts as a cofactor in the neutralization of LPS. J. Exp. Med. 180:1025-1035.

Yuan, K., J. K. Farney, L. K. Mamedova, L. M. Sordillo, and B. J. Bradford. 2013. TNF- $\alpha$ altered inflammatory responses, impaired health and productivity, but did not affect glucose or lipid metabolism in early-lactation dairy cows. PLoS ONE 8:e80316.

Zadnik, T. 2003. A comparative study of the hemato-biochemical parameters between clinically healthy cows and cows with displacement of the abomasum. Acta Vet. (Beogr.) 53:297-310.

Zaloga, G. P. 2000. Ionized hypocalcemia during sepsis. Crit. Care Med. 28:266-268.

Zaloga, G. P., A. Sager, K. W. Black, and R. Prielipp. 1992. Low dose calcium administration increases mortality during septic peritonitis in rats. Circ. Shock 37:226-229.
Zaloga, G. P., S. Willey, P. Tomasic, and B. Chernow. 1987. Free fatty acids alter calcium binding: A cause for misinterpretation of serum calcium values and hypocalcemia in critical illness. J. Clin. Endocrinol. Metab. 64:1010-1014.

Zaragozá, R., A. Bosch, C. Garcia, J. Sandoval, E. Serna, L. Torres, E. R. Garcia-Trevijano, and J. R. Vina. 2010. Nitric oxide triggers mammary gland involution after weaning: Remodelling is delayed but not impaired in mice lacking inducible nitric oxide synthase. Biochem. J. 428:451-462.

Zebeli, Q., D. C. Beitz, B. J. Bradford, S. M. Dunn, and B. N. Ametaj. 2013. Peripartal alterations of calcitonin gene-related peptide and minerals in dairy cows affected by milk fever. Vet. Clin. Pathol. 42:70-77.

Zebeli, Q., S. M. Dunn, and B. N. Ametaj. 2011a. Perturbations of plasma metabolites correlated with the rise of rumen endotoxin in dairy cows fed diets rich in easily degradable carbohydrates. J. Dairy Sci. 94:2374-2382.

Zebeli, Q., S. Sivaraman, S. M. Dunn, and B. N. Ametaj. 2011b. Intermittent parenteral administration of endotoxin triggers metabolic and immunological alterations typically associated with displaced abomasum and retained placenta in periparturient dairy cows. J. Dairy Sci. 94:4968-4983.

Zhang, R., W. Zhu, J. Liu, and S. Mao. 2014. Effect of dietary forage sources on rumen microbiota, rumen fermentation and biogenic amines in dairy cows. J. Sci. Food Agric. 94:1886-1895.

Zhao, X., and P. Lacasse. 2008. Mammary tissue damage during bovine mastitis: Causes and control. J. Anim. Sci. 86:57-65.

Zhou, J., G. Dong, C. Ao, S. Zhang, M. Qiu, X. Wang, Y. Wu, K. Erdene, L. Jin, C. Lei, and Z. Zhang. 2014. Feeding a high-concentrate corn straw diet increased the release of endotoxin in the rumen and pro-inflammatory cytokines in the mammary gland of dairy cows. BMC Vet. Res. 10:172. 